\title{
1 Clinician perspectives on what constitutes good 2 practice in community services for people with 3 Complex Emotional Needs: A qualitative thematic 4 meta-synthesis
}

6 Authors:

7 Jordan Troup ${ }^{1}$, Billie Lever Taylor ${ }^{2}$, Luke Sheridan Rains ${ }^{3}$, Eva Broeckelmann ${ }^{4}$, Jessica Russell ${ }^{4}$, Tamar 8 Jeynes $^{4}$, Chris Cooper ${ }^{5}$, Thomas Steare ${ }^{3}$, Zainab Dedat ${ }^{3}$, Shirley McNicholas ${ }^{6}$, Sian Oram ${ }^{7}$, Oliver 9 Dale $^{8}$, Sonia Johnson ${ }^{3,6}$

1 - Health Service and Population Research Department, Institute of Psychiatry, Psychology \& Neuroscience, King's College London

2 - Division of Psychiatry, University College London 
medRxiv preprint doi: https://doi.org/10.1101/2020.12.15.20248267; this version posted December 16, 2020. The copyright holder for this preprint (which was not certified by peer review) is the author/funder, who has granted medRxiv a license to display the preprint in perpetuity.

It is made available under a CC-BY-ND 4.0 International license .

\section{Abstract \\ 25 Introduction}

The need to improve the quality of community mental health services for people with

27 Complex Emotional Needs (CEN) is recognised internationally and has become a renewed policy

priority in England. Such improvement requires positive engagement from clinicians across the

service system, and their perspectives on achieving good practice need to be understood.

\section{$30 \quad$ Aim}

To synthesise qualitative evidence on clinician perspectives on what constitutes good

practice, and what helps or prevents it being achieved, in community mental health services for

people with CEN.

\section{Methods}

Six bibliographic databases were searched for studies published since 2003 and

supplementary citation tracking was conducted. Studies that used any recognised qualitative

method and reported clinician experiences and perspectives on community-based mental health

services for adults with CEN were eligible for this review, including generic and specialist settings.

Meta-synthesis was used to generate and synthesise over-arching themes across included studies.

\section{Results}

Twenty-nine papers were eligible for inclusion. Six over-arching themes were identified: 1.

42 The use and misuse of diagnosis; 2. The patient journey into services: nowhere to go; 3 . Therapeutic

43 relationships: connection and distance; 4 . The nature of treatment: not doing too much or too little;

44 5. Managing safety issues and crises: being measured and proactive; 6 . Clinician and wider service needs: whose needs are they anyway? The overall quality of the evidence was moderate. 
medRxiv preprint doi: https://doi.org/10.1101/2020.12.15.20248267; this version posted December 16, 2020. The copyright holder for this preprint (which was not certified by peer review) is the author/funder, who has granted medRxiv a license to display the preprint in perpetuity.

It is made available under a CC-BY-ND 4.0 International license .

\section{Discussion}

$47 \quad$ Through summarising the literature on clinician perspectives on good practice for people

48 with CEN, over-arching priorities were identified on which there appears to be substantial

49 consensus. In their focus on needs such as for a long-term perspective on treatment journeys, high

50 quality and consistent therapeutic relationships, and a balanced approach to safety, clinician

51 priorities are mainly congruent with those found in studies on service user views. They also identify

52 clinician needs that should be met for good care to be provided, including for supervision, joint

53 working and organisational support. 


\section{Introduction}

55 The global prevalence of "personality disorder" in the community is estimated to be around $567.8 \%^{(1)}$. This increases to between 40 and $92 \%$ among people who use community secondary mental

57 health care services in Europe ${ }^{(2)}$. High rates of comorbidity with other mental health conditions have 58 been identified ${ }^{(3,4)}$ and people with comorbid conditions appear to have particularly high inpatient 59 and involuntary service use and poor outcomes ${ }^{(5,6)}$. High rates of comorbid physical conditions have 60 also been found ${ }^{(7-9)}$ and evidence suggests shorter life expectancies ${ }^{(10)}$. Impacts on quality of life are 61 comparable to serious somatic illness ${ }^{(11)}$ and a substantial economic cost has been found for health 62 and social care services and society more generally ${ }^{(12,13)}$.

The value of "personality disorder" as a diagnostic category is still contested ${ }^{(14-16)}$. It arguably

provides a basis for clear explanations for service users and reliable categorisation for research.

65 However, it is also criticised as potentially misogynist, and as associated with a heavy burden of 66 stigma that is likely to be difficult to dispel, and with a lack of progress in improving care ${ }^{(17)}$. The 67 papers included in this review largely use the term "personality disorder", but given the gravity of critiques, we choose instead to use the alternative term that has recently come into use to identify the cluster of needs that may lead to a "personality disorder" diagnosis - complex emotional needs 70 (CEN).

In the UK, care provided for people with CEN has recurrently been described as of very variable and often poor quality ${ }^{(18)}$. In 2003, new policy guidance was published aimed at greatly increasing provision of specialist services and improving training and support in generic services ${ }^{(19}$,

${ }^{20)}$. The number of mental health Trusts providing dedicated services increased fivefold over the following decade, but a national survey in 2015 found persisting deficits in access to specialist therapies and to a full spectrum of biopsychosocial interventions, and it remained unclear as to whether overall quality of care had improved ${ }^{(18)}$. Improving care for people with CEN has since 
medRxiv preprint doi: https://doi.org/10.1101/2020.12.15.20248267; this version posted December 16, 2020. The copyright holder for this preprint (which was not certified by peer review) is the author/funder, who has granted medRxiv a license to display the preprint in perpetuity.

It is made available under a CC-BY-ND 4.0 International license .

79 deliver effective treatments for CEN is recognised internationally ${ }^{(24)}$, with formulation of policies and 80 guidelines in various countries aimed at improving care ${ }^{(25,26)}$.

Policy focus on improving CEN care has been accompanied by growing evidence that there

82 are effective psychological treatment options for $\mathrm{CEN}^{(27-32)}$, but that the translation of policy and

83 evidence into service provision has been slow ${ }^{(33)}$. Service users and clinicians have been found to

84 agree that access to specialist services and psychological interventions, interventions to reduce

85 stigma in services, access to specialist consultation services for generic mental health staff, and

86 positive risk management are priorities, but these do not appear to be widely reflected in service

87 provision $^{(34)}$.

As well as lack of resources, clinician-related barriers to service improvement have

repeatedly been found. Stigma related to "personality disorder" diagnosis has recurrently been

90 identified among clinicians: feeling powerless to be helpful, perceived un-treatability,

91 preconceptions about patients and poor CEN understanding have been identified as contributors to

92 this stigma ${ }^{(33,35)}$. Unmet training needs and lack of a clear framework are reported to contribute to

93 negative experiences of working with people with $\mathrm{CEN}^{(36)}$. These do not, however, appear inevitable

94 consequences of working with CEN: in a relatively well-resourced specialist "personality disorder"

95 service setting, Crawford et al. ${ }^{(37)}$ reported relatively low levels of clinician burnout and good

96 satisfaction among staff working with people with CEN. Thus, understanding the perspectives,

97 experiences and attitudes of clinicians and the conditions that allow them to work effectively and

98 without excessive burnout with people with CEN is a crucial element in informing next steps for

99 improving service provision.

The aim of this review was to synthesise existing qualitative evidence on clinician

CEN, and how this could be achieved. Objectives included conducting a systematic search of the 
medRxiv preprint doi: https://doi.org/10.1101/2020.12.15.20248267; this version posted December 16, 2020. The copyright holder for this preprint (which was not certified by peer review) is the author/funder, who has granted medRxiv a license to display the preprint in perpetuity. It is made available under a CC-BY-ND 4.0 International license.

104 This review is part of a broader programme of work conducted by the NIHR Mental Health Policy

105 Research Unit to inform the development of NHS England specialist pathways and to strengthen the

106 evidence base for service development in this field nationally and internationally. Other reviews

107 include a synthesis of qualitive literature on service user perspectives on good practice ${ }^{(38)}$, systematic reviews on treatment effectiveness and cost-effectiveness ${ }^{(39)}$ and a study of service typologies. 
medRxiv preprint doi: https://doi.org/10.1101/2020.12.15.20248267; this version posted December 16 , 2020. The copyright holder for this preprint (which was not certified by peer review) is the author/funder, who has granted medRxiv a license to display the preprint in perpetuity.

It is made available under a CC-BY-ND 4.0 International license .

109 Methods

\section{Information sources and search strategy}

111 The review team developed the protocol in line with PRISMA guidelines ${ }^{(40)}$ and guidance on

112 qualitative meta-syntheses ${ }^{(41)}$ in collaboration with a project-specific working group of lived-

experience researchers and subject experts. The protocol was registered prospectively on PROSPERO

(CRD42019145615), as was the protocol for the wider programme of work (CRD42019131834).

One search strategy was developed for all the reviews in the programme (see Appendix A).

Search terms were built around key words and subject headings relevant to CEN and related needs,

community mental health services, and eligible study designs including qualitative, quantitative and

guidelines. Comprehensive searches were conducted of MEDLINE (January 2003 - December 2019),

Embase (January 2003 - December 2019), HMIC (January 2003 - December 2019), Social Policy and

Practice (January 2003 - December 2019), CINAHL (January 2003 - December 2019) and ASSIA

(January 2003 - January 2019). No limits were placed on the language or country, and a limit of 2003

or later was placed on the date to capture perspectives of greater contemporary relevance.

software, and duplicates were removed. Titles and abstracts were double screened by two NIHR

Mental Health Policy Research Unit researchers for all the reviews together and full text screening

was performed on potentially eligible papers for this review. Supplementary searching included a

call for evidence publicised via the study team's networks, relevant professional associations and

social media, forward and backward citation tracing of included articles, and reference lists of other

relevant systematic reviews found in an additional systematic review search of EMBASE and

MEDLINE (January 2003 - November 2019). Grey literature was identified through web searches and

the above bibliographic database search. All included studies and $20 \%$ of those excluded were 
medRxiv preprint doi: https://doi.org/10.1101/2020.12.15.20248267; this version posted December 16 , 2020. The copyright holder for this preprint (which was not certified by peer review) is the author/funder, who has granted medRxiv a license to display the preprint in perpetuity.

It is made available under a CC-BY-ND 4.0 International license .

\section{Eligibility criteria}

134 Studies using recognised qualitative data collection and analysis methods to explore clinician

perspectives on good practice in community mental health services for people with CEN were

included. Studies were eligible if they reported the relevant perspectives of any mental health

professional with experience of working with people with CEN or related needs (e.g., recurrent self-

harm). Eligible settings were community-based mental health services, including mental health care

in primary care settings, generic community mental health teams, and specialist services for people

with CEN. Residential, forensic, or crisis services, or specialist services for different conditions were

excluded. Papers were excluded if the service target population were primarily below the age of 16 ,

unless focussing on transition into adult services. Published and grey literature were eligible, except

for case studies, dissertations and theses. (See Appendix B for full eligibility criteria). Most of the

papers used "personality disorder" to describe the sample, but here we use the term CEN in view of

the contentious nature of the "personality disorder" diagnosis.

146 Quality assessment and analysis

Study characteristics were extracted into a Microsoft Excel form. The Critical Appraisal Skills

Programme (CASP) Qualitative Checklist ${ }^{(42)}$ was used to perform quality assessments. Study quality was not used to determine eligibility but is reported below. Text from results sections of included articles was entered verbatim into the coding software NVivo for thematic meta-synthesis ${ }^{(41)}$ and linked to individual study characteristics such as types of clinicians, services, and interventions. For stage one, articles were coded line-by-line by one of two researchers and $20 \%$ of papers were double coded to produce an initial framework. A descriptive thematic framework emerged from

154 further discussion between the two researchers for stage two, iteratively developed as codes were 155 merged and grouped hierarchically. Finally, analytic themes were generated to address the research 156 question for stage three. Analysis was finalised collaboratively by a small team of reviewers and 
medRxiv preprint doi: https://doi.org/10.1101/2020.12.15.20248267; this version posted December 16, 2020. The copyright holder for this preprint (which was not certified by peer review) is the author/funder, who has granted medRxiv a license to display the preprint in perpetuity.

It is made available under a CC-BY-ND 4.0 International license.

157

experts by experience and occupation. The analysis process included considering whether there

158 were sub-group differences related to major study characteristics such as country of publication.

159 
medRxiv preprint doi: https://doi.org/10.1101/2020.12.15.20248267; this version posted December 16, 2020. The copyright holder for this preprint (which was not certified by peer review) is the author/funder, who has granted medRxiv a license to display the preprint in perpetuity. It is made available under a CC-BY-ND 4.0 International license .

\section{Results}

161 A total of 29 papers (drawing on 27 unique datasets) were eligible for inclusion ${ }^{(37,43-70)}$ (Fig

162 1), representing perspectives from at least 550 clinicians. Clinicians represented a variety of

163 professions and included psychologists, social workers, psychiatric nurses, occupational therapists,

164 psychiatrists, family doctors (known as General Practitioners or 'GPs' in the UK) and counsellors

165 (Table 1). They worked in a range of settings from primary through tertiary (non-residential) care

166 and offered anything from specific interventions (e.g., Dialectical Behavioural Therapy,

167 Mentalisation-Based Interventions, Cognitive Analytic Therapy, etc.) to more general and varied

168 support. While we use the term "CEN", service users in most included studies were identified as

169 having "personality disorder" or "borderline personality disorder".

\section{Fig. 1. PRISMA Diagram}


172 Table 1. Study Characteristics

\section{First Author, Year. Title.}

\begin{tabular}{|c|c|c|c|c|}
\hline $\begin{array}{l}\text { Clinician type } \\
\text { Sample size }\end{array}$ & Data collection & Service / setting, Location & Target population & $\begin{array}{l}\text { Intervention if } \\
\text { applicable }\end{array}$ \\
\hline $\begin{array}{l}\text { Case managers: psychiatric nurses and occupational therapists } \\
\mathrm{N}=8\end{array}$ & $\begin{array}{l}\text { Five 3-mothly focus } \\
\text { groups of 3-5 } \\
\text { clinicians }\end{array}$ & $\begin{array}{l}\text { Community mental health } \\
\text { service, Australia }\end{array}$ & $\begin{array}{l}8 \text { female service users diagnosed } \\
\text { with 'BPD' (DSM-IV) and }<7 \text { on DIB- } \\
\text { R. }\end{array}$ & $\mathrm{MBI}$ \\
\hline $\begin{array}{l}\text { Carmel, } 2014 .{ }^{(44)} \text { Barriers and solutions to implementing dialectical behavior } \\
\text { Clinicians NS } \\
N=19 / 34\end{array}$ & $\begin{array}{l}\text { therapy in a public be } \\
\text { Structured phone } \\
\text { interviews }\end{array}$ & $\begin{array}{l}\text { havioral health system. } \\
\text { Community mental health anc } \\
\text { substance abuse agencies } \\
\text { within a } \\
\text { public behavioral health } \\
\text { system, Northern California }\end{array}$ & People with 'BPD' & DBT \\
\hline $\begin{array}{l}\text { Crawford, } 2007{ }^{(46)} \text { Learning the lessons: a multi-method evaluation of dedic } \\
\text { Service managers, front-line clinicians (range), referrers, commissioners. } \\
\mathrm{N}=89 \text { service providers, } 26 \text { referrers, } 13 \text { commissioners from across all } 1 \\
\text { dedicated services. }\end{array}$ & $\begin{array}{l}\text { Comprehensive } \\
\text { evaluation including } \\
\text { in-depth qualitative } \\
\text { interviews }\end{array}$ & $\begin{array}{l}\text { d services for people with perso } \\
11 \text { 'Pilot' dedicated services, } \\
\text { England }\end{array}$ & $\begin{array}{l}\text { nality disorder. } \\
\text { People with 'PD' - range of criteria } \\
\text { across services }\end{array}$ & $\begin{array}{l}\text { Range - } \\
\text { psychotherapeutic, } \\
\text { social, occupational }\end{array}$ \\
\hline $\begin{array}{l}\text { Crawford, } 2007{ }^{(45)} \text { Lessons learned from an evaluation of dedicated commu } \\
\text { See Crawford } 2007 a \text {, above }\end{array}$ & ty-based services for & eople with personality disc & & \\
\hline $\begin{array}{l}\text { Crawford, } 2010 .^{(37)} \text { Job satisfaction and burnout among staff working in com } \\
\text { Service managers and 'front-line' clinicians: therapists, psychotherapists, } \\
\text { nurses, psychologists, social workers, psychiatrists, occupational } \\
\text { therapists, art therapists, support workers, and employed service users. } \\
\mathrm{N}=89 \text { from across all } 11 \text { dedicated services }\end{array}$ & $\begin{array}{l}\text { munity-based persona } \\
\text { Comprehensive } \\
\text { evaluation including } \\
\text { in-depth qualitative } \\
\text { interviews }\end{array}$ & $\begin{array}{l}\text { lity disorder services. } \\
11 \text { 'Pilot' dedicated services, } \\
\text { England }\end{array}$ & People with 'PD' & $\begin{array}{l}\text { Range: } \\
\text { psychotherapeutic, } \\
\text { social, occupational }\end{array}$ \\
\hline $\begin{array}{l}\text { Donald, } 2017 .{ }^{(47)} \text { Clinician perspectives on recovery and borderline personali } \\
\text { Social workers, nurses, psychologists, one psychiatry registrar and one } \\
\text { consultant psychiatrist } \\
\mathrm{N}=16\end{array}$ & $\begin{array}{r}\text { ydisorder.? } \\
\text { Interviews }\end{array}$ & $\begin{array}{l}\text { Clinicians mostly from one } \\
\text { specialist service, and two } \\
\text { from a generalist service, } \\
\text { Australia }\end{array}$ & People with 'PD' / 'BPD' & Range \\
\hline $\begin{array}{l}\text { Fanaian, } 2013{ }^{(48)} / \text { mproving services for people with personality disorders: } \\
\text { Recognised specialists and experts in 'PD' } \\
N=60\end{array}$ & $\begin{array}{l}\text { Written group } \\
\text { responses to one } \\
\text { question during } \\
\text { clinical and } \\
\text { scientific meeting }\end{array}$ & $\begin{array}{l}\text { inicians. } \\
\text { Range of public and private } \\
\text { services across Australia }\end{array}$ & NA & NA \\
\hline
\end{tabular}

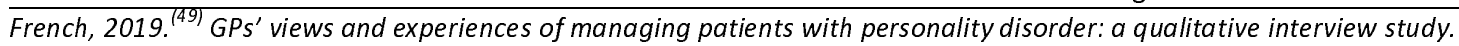




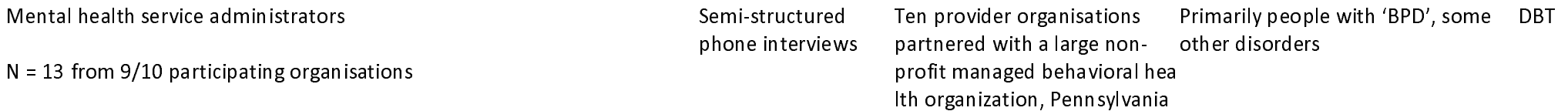

\section{$\mathrm{N}=$ All staff from network}

Hutton, 2017. ${ }^{(52)}$ Switching roles: a qualitative study of staff experiences of being dialectical behaviour therapists within the National Health Service in England.
Clinicians from 3 DBT teams: social workers, community psychiatric nurses Semi-structured and clinical psychologists interviews
3 DBT teams within 1 Trust
(alongside secondary care
eople with

service roles), England

$\mathrm{N}=6 / 24$ from all 3 teams

Koekkoek, 2009. ${ }^{(53)}$ Clinical problems in community mental health care for patients with severe borderline personality disorder. Experts had at least som patients, but worked in a

Lamph, 2019. ${ }^{(54)}$ Personality disorder co-morbidity in primary care 'Improving Access to Psychological Therapy' services: A qualitative study exploring professionals' perspectives of working with this patient group. [?

Trained and trainee psychological wellbeing practitioners, high intensity Interviews cognitive behavioural therapist, clinical psychologists, clinical leaders and IAPT clinical service managers
IAPT in 2 localities (primary care), England

\section{'Peop'}

IAPT interventions e.g. CBT

$\mathrm{N}=28$

Langley, 2005. ${ }^{(55)}$ Trust as a foundation for the therapeutic intervention for patients with borderline personality disorder.

Multidisciplinary clinicians with extensive experience in the manaement Individual interviews Psychiatic Commu of 'BPD' in both private and public systems: psychiatrists, psychiatric

nurses, a psychiatric social worker, a clinical psychologist and a counselling or focus group Services, South Africa

People with ‘PD' (DSM-IV)

NA

psychologist

$\mathrm{N}=10$

Lee, 2008. ${ }^{(56)}$ A pilot personality disorder outreach service: development, findings and lessons learnt

Consultant psychiatrists

Pilot 'PD' outreach service

(1)


$\mathrm{N}=$ Unclear. $13 \mathrm{SUs}$ in case series element, unknown number of

interviews (secondary care), England

psychiatrists from across 8 teams, from which 2 were selected for outreach

service.

Morant, 2003. ${ }^{(57)}$ A multi-perspective evaluation of a specialist outpatient service for people with personality disorders.

Referrers to service: consultant psychiatrists, social workers, one clinical Multi-people with personality disorders.

specialist

$\begin{array}{ll}\text { Multi-perspective / } & \text { Specialist 'PD' outreach } \\ \text { multi-method } & \text { service (clinicians primaril }\end{array}$

evaluation including from CMHTs), England

People with moderate to sever 'PD'

semi-structured

interviews
Individual treatment

(cognitive therapy),

Group psychotherapy

(psychodynamic), Art

psychotherapy (group)

$\mathrm{N}=12$

clents with borderline personality disorder.

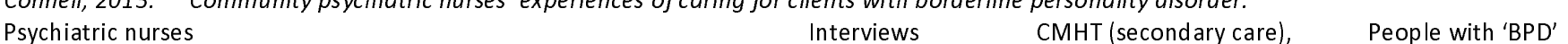

$\mathrm{N}=10$

Ireland

Perseius, $2003{ }^{(60)}$ Treatment of suicidal and deliberate self-harming patients with borderline personality disorder using dialectical behavioral therapy: the patients' and the therapists' perceptions.

DBT therapists: a psychiatrist, a registered nurse, and cognitive psychotherapists
Individual free-

format questionnaire

DBT Team, Sweden

and group interview
People with 'BPD' or related

symptoms
DBT

$\mathrm{N}=4 / 4$

\section{Perseius, 20}

personality symptoms.

Physicians, psychologists, registered nurses, mental health care assistants An individualopen and one occupational therapist

question, free text

answer

$\mathrm{N}=22$

questionnaire and a

group interview (and

burnout inventory)

Pigot, 2019. ${ }^{(61)}$ Barriers and facilitators to the implementation of a stepped care intervention for Mental health clinicians and managers actively involved in the Semi-structured intervention

interview

Publicly funded open access People with 'PD', particularly 'BPD' Stepped-care approach provider of health and medical

services, Australia

$\mathrm{N}=21 / 46$

Priest, 2011. ${ }^{(62)}$ How can mental health professionals best be supported in working with people who experience significant distress? Social workers, nurses, occupational therapists, psychiatrists, psychologists Focus group CMHTs and CSMT (secondary and support workers

care), England

MHT case load / People with 'PD' / NA

people who experience 'significant distress'

$\mathrm{N}=26$

Riza, 2012. ${ }^{(63)}$ 'There's always this sense of failure': an interpretative phenomenological analysis of primary care counsellors' experiences of working with the borderline client Experienced counsellors (senior practitioners) Semi-structured Primary care, England

People with 'BPD' (clinician 
$\mathrm{N}=5$

Stalker, 2005. ${ }^{(64)}$ It is a horrible term for someone': service user and provider perspectives on 'personality disorder'.

Psychiatrists, three community psychiatric nurses, one clinical psychologist, Interviews $\quad$ CMHTs through Mental Health People with 'PD'

Resource Centres, Scotland and an administrator

$\mathrm{N}=12$ Stroud, $2013 .^{(65)}$ Working with borderline personality disorder: A small-scale qualitative investigation into community psychiatric nurses' constructs of borderline personality disorder.
$\begin{array}{lll}\text { Community psychiatric nurses } & \text { Semi-structured } & \text { CMHT, Wales }\end{array}$ Semi-structure

$\mathrm{N}=4$

\section{personality disorder diagnosis.}

Sulzer, 2016 ${ }^{(66)} /$ mproving patient-centered communication of the borderline personality disorder diagnosis.
Psychiatrists, Psychologists, Clinical Social Workers and BPD activists Semi-structured Clinicians interviews

America

$\mathrm{N}=32$

Thompson, 2008. ${ }^{(67)}$ Multidisciplinary community mental health team staff's exp All eligible clinicians: social workers and community psychiatric nurses

\section{Structured, open-}

vel' training course in cognitive analytic therapy.

$\mathrm{N}=12$

CMHT (secondary care), UK

People with complex needs e.g.,

Vyas, 2017.9.

Clinicians working in a TC

staff. Therapeutic Con interviews

people presenting with features of 'PD'

$\mathrm{N}=8$

A long-standing TC, UK

urnal of Therapeutic Communities.

People with 'EUPD' / 'emotional instability'

Wilson, $2018{ }^{(69)}$ Experiences of parenting and clinical intervention for mothers affected by personality disorder: a pilot qualitative study combining parent and clinician perspectives.

Referring CAMHS clinicians

$\mathrm{N}=5$ Semi-structure interviews Four CAMHS teams referred into the Helping Families Programme
'Mothers with 'PD' Who had a child Helping Familes

(living with them) aged 3-11 years Programme-parenting with a behavioural and/or emotionaland clinical

intervention disorder

Wlodarczyk, 2018. ${ }^{(70)}$ Exploring General Practitioners' Views and Experiences of Providing Care to People with Borderline Personality Disorder in Primary Care: A Qualitative Study in Australia. Any currently practicing GPS

Focus groups

Primary care, Australia

People with 'BPD'

$\mathrm{N}=12$ Disorder. GP = General Practitioner. IAPT = Improving Access to Psychological Therapies. CMD =Common Mental Disorders. CBT $=$ Cognitive Behavioural Therapy. SU = Service User. SAP = Standardised Assessment of Personality. CMHT = Community Mental Health Team. CSMT = Community Substance Misuse Team. CAT = Cognitive Analytic Therapy. $T C=$ Therapeutic Community. EUPD = Emotionally Unstable Personality Disorder. CAMHS = Child and Adolescent Mental Health Service. 
medRxiv preprint doi: https://doi.org/10.1101/2020.12.15.20248267; this version posted December 16, 2020. The copyright holder for this preprint (which was not certified by peer review) is the author/funder, who has granted medRxiv a license to display the preprint in perpetuity. It is made available under a CC-BY-ND 4.0 International license .

178 Quality appraisal indicated that the majority of studies appropriately used qualitative

179 methodology ( $n=28)$, employed an appropriate research design $(n=28)$, and described clear findings

180 ( $n=28)$. Most studies also presented clear aims ( $n=27)$ and used appropriate data collection methods

181 ( $n=26)$. However, a number of papers did not provide enough information to determine whether the

182 data analysis was sufficiently rigorous $(n=6)$, whether the recruitment strategy was appropriate

183 ( $n=11$ ), nor whether ethical issues had been sufficiently considered ( $n=12$ ). Only 5 papers in total

184 adequately considered the relationship between researcher and participants (Table 2). 
185 Table 2. Quality assessment according to the Critical Appraisal Skills Programme

\begin{tabular}{|c|c|c|c|c|c|c|c|c|c|c|}
\hline First Author, Year. & $\begin{array}{l}\text { 1. Was there a } \\
\text { clear statement of } \\
\text { the aims of the } \\
\text { research? }\end{array}$ & $\begin{array}{l}\text { 2. Is a qualitative } \\
\text { methodology } \\
\text { appropriate? }\end{array}$ & $\begin{array}{l}\text { 3. Was the } \\
\text { research design } \\
\text { appropriate to } \\
\text { address the aims } \\
\text { of the research? }\end{array}$ & $\begin{array}{l}\text { 4. Was the } \\
\text { recruitment } \\
\text { strategy } \\
\text { appropriate to the } \\
\text { aims of the } \\
\text { research? }\end{array}$ & $\begin{array}{l}\text { 5. Was the data } \\
\text { collected in a way } \\
\text { that addressed the } \\
\text { research issue? }\end{array}$ & $\begin{array}{l}\text { 6. Has the } \\
\text { relationship } \\
\text { ebetween } \\
\text { researcher and } \\
\text { participants been } \\
\text { adequately } \\
\text { considered? }\end{array}$ & $\begin{array}{l}\text { 7. Have ethical } \\
\text { issues been taken } \\
\text { into } \\
\text { consideration? }\end{array}$ & $\begin{array}{l}\text { 8. Was the data } \\
\text { analysis } \\
\text { sufficiently } \\
\text { rigorous? }\end{array}$ & $\begin{array}{l}\text { 9. Is there a clear } \\
\text { statement of } \\
\text { findings? }\end{array}$ & $\begin{array}{l}\text { 10. How valuable } \\
\text { is the research? }\end{array}$ \\
\hline Bosanac, $2015^{(43)}$ & Yes & Yes & Yes & Can't Tell & Yes & No & No & Can't Tell & Yes & Unclear \\
\hline Carmel, 2014 & Yes & Yes & Yes & Yes & Yes & No & No & Can't Tell & Yes & Valuable \\
\hline Crawford, $2007 a^{(46)}$ & Yes & Yes & Yes & Yes & Yes & No & Yes & Yes & Yes & Valuable \\
\hline Crawford, $2007 \mathrm{~b}^{(45)}$ & $*$ & & & & & & & & & \\
\hline Crawford, $2010^{(37)}$ & Yes & Yes & Yes & Yes & Yes & No & Yes & Yes & Yes & Valuable \\
\hline Donald, $2017^{(47)}$ & Yes & Yes & Yes & Can't Tell & Yes & No & Can't tell & Yes & Yes & Valuable \\
\hline Fanaian, $2013^{(48)}$ & Yes & Yes & Yes & Can't Tell & Can't Tell & No & Yes & Yes & Yes & Valuable \\
\hline French, $2019^{(49)}$ & Yes & Yes & Yes & Yes & Yes & No & Can't Tell & Yes & Yes & Valuable \\
\hline Herschell, $2009^{(50)}$ & No & Yes & Yes & Yes & Yes & No & Yes & Yes & Yes & Valuable \\
\hline Hogard, $2010^{(51)}$ & Yes & Yes & Yes & Can't Tell & Can't Tell & No & No & Can't Tell & Yes & Unclear \\
\hline Hutton, $2017^{(52)}$ & Yes & Yes & Yes & Yes & Yes & No & Yes & Yes & Yes & Valuable \\
\hline Koekkoek, $2009^{(53)}$ & Yes & Yes & Yes & Yes & Yes & No & No & Yes & Yes & Valuable \\
\hline Lamph, $2019^{(54)}$ & Yes & Yes & Yes & Yes & Yes & No & Can't Tell & Yes & Yes & Valuable \\
\hline Langley, $2005^{(55)}$ & Yes & Yes & Yes & Can't Tell & Yes & No & Yes & Yes & Yes & Valuable \\
\hline Lee, $2008^{(56)}$ & No & Can't Tell & Can't Tell & Can't Tell & Can't Tell & No & No & Can't Tell & No & Unclear \\
\hline Morant, $2003^{(57)}$ & Yes & Yes & Yes & Yes & Yes & No & Can't Tell & Can't Tell & Yes & Valuable \\
\hline $\mathrm{O}^{\prime}$ Connell, $2013^{(58)}$ & Yes & Yes & Yes & Can't Tell & Can't Tell & No & Yes & Can't Tell & Yes & Valuable \\
\hline Perseius, $2003^{(60)}$ & Yes & Yes & Yes & Yes & Yes & Yes & Yes & Yes & Yes & Valuable \\
\hline Perseius, $2007^{(59)}$ & Yes & Yes & Yes & Yes & Yes & No & Yes & Yes & Yes & Valuable \\
\hline Pigot, $2019^{(61)}$ & Yes & Yes & Yes & Yes & Yes & No & Yes & Yes & Yes & Valuable \\
\hline Priest, $2011^{(62)}$ & Yes & Yes & Yes & Can't Tell & Yes & No & Can't Tell & Yes & Yes & Valuable \\
\hline Rizq, $2012^{(63)}$ & Yes & Yes & Yes & Yes & Yes & Yes & Yes & Yes & Yes & Valuable \\
\hline Stalker, $2005^{(64)}$ & Yes & Yes & Yes & Can't Tell & Yes & No & Yes & Yes & Yes & Valuable \\
\hline Stroud, $2013^{(65)}$ & Yes & Yes & Yes & Can't Tell & Yes & Yes & Yes & Yes & Yes & Valuable \\
\hline Sulzer, $2016^{(66)}$ & Yes & Yes & Yes & Yes & Yes & No & Yes & Yes & Yes & Valuable \\
\hline Thompson, $2008^{(67)}$ & Yes & Yes & Yes & Yes & Yes & No & Yes & Yes & Yes & Valuable \\
\hline Vyas, $2017^{(68)}$ & Yes & Yes & Yes & Can't Tell & Yes & Yes & Can't Tell & Yes & Yes & Valuable \\
\hline Wilson, $2018^{(69)}$ & Yes & Yes & Yes & Yes & Yes & No & Can't Tell & Yes & Yes & Valuable \\
\hline Wlodarczyk, $2018^{(70)}$ & Yes & Yes & Yes & Yes & Yes & No & Yes & Yes & Yes & Valuable \\
\hline
\end{tabular}

$186{ }^{*}$ Crawford2007b is a short published paper based on Crawford 2007a which is a long-form report and provides details in full. Only the quality ratings of

187 Crawford 2007a have therefore been provided. 
medRxiv preprint doi: https://doi.org/10.1101/2020.12.15.20248267; this version posted December 16, 2020. The copyright holder for this preprint (which was not certified by peer review) is the author/funder, who has granted medRxiv a license to display the preprint in perpetuity. It is made available under a CC-BY-ND 4.0 International license .

189 diagnosis; 2. The patient journey through services: nowhere to go; 3 . Therapeutic relationships:

190 connection and distance; 4 . The nature of treatment (including intervention models): not doing too

191 much or too little; 5. Managing safety issues and crises: being measured and proactive; and 6.

192 Clinician and wider service needs (including clinician support, interagency working and the wider

193 system, and establishing new services, interventions and skills): whose needs are they anyway?

194 These themes are further described below. Table 3 gives further supporting quotes from the studies

195 relevant to each theme. While conducting the analysis, variations by setting or by participant

196 characteristics were considered. Substantial variations by country or by year of data collection were

197 not identified but variations between types of clinician and service setting were found: these are

198 described where relevant. 
[] [ ] "The global, all-encompassing nature of the diagnosis, coupled with the view that it was untreatable, could have a devastating impact on the individual, while also leading to a lack of therapeutic optimism on the part of clinicians. Personality disorder?was seen as having all the drawbacks of a mental illness diagnosis, especially in terms of stigma, but none of the benefits, particularly access to services. Likewise, the contested and uncertain nature of personality disorder limited the potential for users to gain some control over their condition through knowledge and information. The diagnosis could lead to people facing discrimination and stereotyping within mental health services, within generic health and social care services and within society at large, with individuals being labelled as attention-seeking and demanding."国]

"A different view expressed by some service providers was that personality disorder is best understood as a form of social deviance or culturallerule-breaking. One respondent described people with a personality disorder diagnosis as those? whose behavior, attitudes, lifestyles seem to consistently transgress cultural norms, which brings them into conflict with other people, in the absence of any symptom of an underlying mental illness...' These respondents believed that a diagnosis of personality disorder could simply serve to medicalize or pathologize an individual's feelings of distress." (Stalker et al., 2005) ${ }^{(64)}$ [e]

\section{The Patient Journey] into[Services: Nowhere to Gol?}

[. [- 'Several GPs described adopting a strategy of 'writing-up', or embellishing descriptions of a patient's risk status in order to ensure that the patient was seen by secondary care services. On the other hand, faced with an overly cautious response from IAPT, several GPs described emphasising the patient's more 'agreeable' mental health conditions, such as depression or anxiety, to maximise the chances of the patient being accepted into treatment."

"GPs also described patients with PD as having to endure particularly long waits, before being seen-waiting times that often far exceeded those experienced by patients with other mental health problems. Indeed, several GPs described patients with PD having to wait over 12 months for treatment. They felt shortening waiting times would

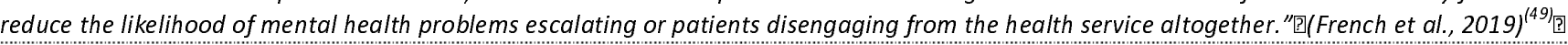

[) 0 "Unfortunately, because of the model of stepped care in the Trust, there were barriers to primary care staff wishing to refer patients directly into a tertiary service, such as a specialist psychology service for people with PD. '... Have a real problem in getting through the cycle of exclusion: GPs who identify suitable patients cannot refer to [tertiary psychology service], [athey have to refer to the CMHT and get them to take person on... so we cannot keep clients out of mental health services, [and CMHTs can say they won't take them, as don't meet their criteria. "']

"The majority of ]referrers made reference to the assessment as an important part of the process, and some stated that having an assessment was one of the reasons for referring someone to the service. Referrers linked to two services made specific comment of how much they valued the provision of a comprehensive assessment, even if the service user was not taken on. Benefits included helping the referrer to develop their own management plan or to better understand the service user's problems and building confidence and trust for the service user." (Crawford et al., 2007) ${ }^{(46)}$ [?

\section{Therapeutic Relationships: Connection and Distance?}

[3] [- "A few service provider respondents however were careful not to locate 'the problem' within individual service users. They believed that unhelpful responses from mental health services were often responsible for compounding people's problems shown, for example, in judgemental attitudes expressed by some staff who reportedly used words like 'manipulative', 'attention-seeking' and 'demanding' to stereotype people with personality disorder diagnoses."[(Stalker et al., 2005) ${ }^{(64)}$ [] [ "Patients have a hard time trusting a therapist and may only do so after quite some time, which professionals tend to underestimate. These people really need a secure attachment, they fight it for a year, claim help and then reject it again. But if one succeeds in breaking that pattern, one can really mean something.'DOn the other hand, a dependency relationship may be perceived as dangerous in community mental health care as many patients become long-term users that lay a large claim on scarce resources, according to the experts."](Koekkoek et al., 2009) $)^{(53)}$ [?

[. [. "Clare uses the powerful meta phor of a nursing mother to describe the nature of the relationship. She seems to feel ambivalent about being at the mercy of a. newborn 回baby, whose need to feed on demand cannot be denied. It is as if her capacity to psychologically nourish these clients is being ruthlessly exploited:? they latch onto you and it's like[suck[suck[suck!suck."”

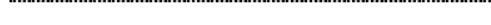


"...For [clinician], the encounter with the depth of his clients' needs and their sense of emptiness or lack of [self ushers [in an uncomfortable awareness of his own vulnerability and inner emptiness: 'What you're met with is a neediness which is bottomless really ... and it's almost collateral to the emptiness is the neediness and lack of self... what a lot of borderline patients talk about is being in nothingness, their experiences of nothingness, they have the most acute sense of nothingness that I think you'll ever come across ... it's within that that the draining and the lexhaustingness?of it all, because we all experience emptiness to some degree, but I think these clients ... they almost get a heightened sense of all these things ... so I almost get a heightened sense of what humanity is and vulnerability."

\section{The Nature of Treatment: Not doing too much or too little?}

[. [. "Some of the experts are particularly critical of the apparent denial that can be seen to occur in several settings of the long-term nature of the problems of the patient with a severe BPD. That is, a rather naïve and overly "optimistic" attitude characterizes professionals who rapidly discharge such patients. According to the experts, in fact, such optimism is simply "therapeutic nihilism" disguised as optimism... The combination of powerlessness and the blaming of the patient for any lack of progress may result in non-therapeutic]behaviors? therapeutic encounter to doing as little as possible and simply hoping that a crisis does not arise. Further referral of the patient without substantial justification of the reasons for doing this is another example of really doing nothing. 'Professionals have many strategies to do completely nothing in therapeutic encounters with the patient."

回

"One respondent used the term 'hard to engl

of people's lives." (Stalker et al., 2005) ${ }^{(64)}$ ]

[1] [A continuum of severity and complexity was referred to, with acknowledgement that those who were deemed less complex could respond well to routine IAPT treatment but people with what was deemed to be more severe presentations would struggle with routine treatment as they could oscillate from one problem to the next on a weekly basis making adherence to the IAPT model and protocol delivered therapies very challenging to deliver. Participant frustration at the lack of treatment options and the constraints of time-limited therapy[ was?commonly reported."回(Lamph et al., 2019) ${ }^{(54)}$ ]

"In recognition of the heterogeneous needs and capacities of people with PD, most of the pilots set out to provide a range of services. Provision? $\mathrm{l}$ more than one service or treatment option also enabled most pilots to present a choice to potential service users, a capacity that many believed important in promoting engagement."[] "Discharge or disengagement] from? the service is likely to be difficult and threatening for some service users: it may be viewed as abandonment and may precipitate an increase in behaviour designed to demonstrate need or risk. Some services address this by working toward discharge or self-sufficiency as a specific goal at a specific time from the point of engagement, while others have provisos for re-entry into the service. Some services are developing models for less intensive, ongoing support so that discharge need not be absolute... Some staff of open-ended services felt that there should be a cut-off point, and that allowing ongoing use of a service encourages dependence and reduces motivation and the development of coping strategies for existing clients, while denying others the opportunity of using the service." [? (Crawford et al., 2007) ${ }^{(46)}$ 国

[2] "Look, although I'm not doing my job properly here - I'm seeing people for longer, I'm, you know, they're dropping in, topping them up every so often when they need it -

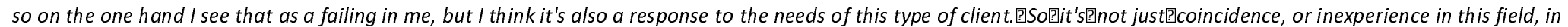
this type of work with personality disorder."'

"Michael's account exemplifies counsellors' struggle with what appears to be an insoluble paradox - that the establishment of a much-needed therapeutic relationship is precisely what is most likely to evoke yet further trauma for the borderline client when it ends: ... they could experience it as a good experience of another person - that not everyone's going to destroy them, if you want, which is their fantasy... But at the same time, youlthen are[ faced with the whole thing [af?ending that. And are you going to do them any good? And are we really just re-traumatising these people again?'” $(\text { Rizq, 2012) })^{(63)}$ 还

] Intervention "I think an ability to manage their emotions better, because they usually come into our service because, on alday to daylbasis, their emotions are causing them all sorts of models? difficulties in their personal life, with regard to employment, education, leisure activities, and they are perhaps just going from one crisis or problem, to another, and no wonder they are anxious and depressed, which obviously brings them into our world." (Lamph et al., 2019) (54) $^{\text {] }}$

"Many relatives have high expectations of the mental health system but are disappointed over time, which also results in a poor relationship between the family of the patient and professionals. "国(Koekkoek et al., 2009) ${ }^{(53)}$ [? 

staff and service users, and the Association of Therapeutic Communities. A TC is: A safe and secure environment, a place of safety, where people can come and learn how to make relationships... It creates an environment where people engage in normal interactions that trigger behaviours and feelings they have difficulty with: it's got to be an emotionally safe environment, where they can reflect on and interpret those feelings, so they don't have adverse consequences. "ㅁ. (Crawford et al. 2007) ${ }^{(46)}$ [?

\section{Managing国Safety? Concerns国and Crises: Being Measured and Proactive}

[2] [- [s a CPN if something goes wrong then the buck stops with you and then I think that does not help staff to take positive risks. Staff are very defensive in their practice and very risk adverse and in DBT it is about accepting that this is a risky client group and if we wrap them up in cotton wool all the time that is not treating them and I think it is about having a service that is prepared to take well thought out positive risks and I don't think we are there yet. Because I think staff are so scared of things going wrong and them getting the blame and being sued it is very hard to allow clients to have some responsibility. ${ }^{\prime \prime}\left(\right.$ Stroud and Parsons, 2013) ${ }^{(65}{ }^{\text {De }}$

3. [) "There is general recognition that no external agent can stop a person self-harming: responsibility lies with the only person who can change the course of events, the service user themselves. Putting self-harmers into hospital on suicide watch backfires: it takes responsibility away from them. It is better to talk to them about how it comes about and find something to divert them from it."

"Several of the pilot services also have guidelines governing staff-client interaction, such as limits on the amount of time clients can spend in one-to-ones during crises.... [.] Staff suggest that the act of recording messages has advantages over phone calls because it introduces a slight delay which inhibits impulsiveness and allows a natural pause for consideration. Other services have suggested that e-mail messages to the service have a similar function, even though they will not be read until the next working day... IMethods for supporting people in crisis developed by pilot services seek to actively involve service users and tend not to provide an instant response. Service providers report that if people have been helped to prepare for crises, a delayed response can help ensure the service user plays an active role in crisis management." (Crawford et al., 2007) ${ }^{(46)}$ 回

Clinician and Wider Service Needs: Whose Needs Are They Anyway?

[. Clinician "Some participants were clear that it was not simply more support that was needed, but a particular type?and quality of clinical supervision. Clare was critical of the supervision she was offered in primary care, feeling that it was based on providing expert advice and technical information, rather than examining complex unconscious process issues within the therapeutic relationship. She seems to feel that this is part of a more general tendency where increasingly managed or professionalised forms of practice now take precedence over the emotional aspects of therapeutic work: '... it's all about have you filled in the right form, rather than 'what do you need for your work in terms of emotional support?"

"I think that people with personality disorder need llsome kind of secure?base if you're going to work with them... I also work in secondary care you see and when you work in secondary care, it's easier to manage people with personality disorder because there's somebody if they do feel suicidal or make a suicide attempt, there's some structure

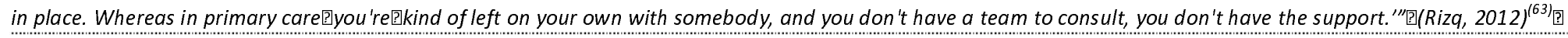
"It actually helps workers to survive in their work, if they have a place to think ... One of the main theories about, you know, personality disordered people is that they don't have the capacity to reflect on themselves and so if [they are involved with] an organization that equally can't reflect, you're going to have this sort of mirroring that goes all the way up from the client themselves all the way up through the organization that's trying to help the client." "Q (Crawford et al., 2010) ${ }^{(37)}$ [?

[3] [- "Participants noted the flattened hierarchy principle encouraged them to feel that they had a voice in TC and encouraged relational working by bridging the gap between therapists and members: "I felt more confident, I felt like I did have a voice in the group." (Vyas et al., 2017) ${ }^{(68)}$ ?

[3] "In effect, there are all sorts of expectations on the part of all the players in the system, which may mean that those with the least power are the least likely to have their expectations met."

"Differences in models of understanding might at times be helpful: 'The opportunity to have a number of disciplines, and talk through a particularly difficult case ... that's the strength of the team ... it is that exchange of ideas and it does alleviate things an awful lot'... When asked, 'what helps you keep working with someone when you feel you've tried everything and nothing seems to have helped?', workers reported that joint working, attention to the needs of workers, including good clinical supervision, trying alternative interventions and working with people who have different models of understanding and alternative perspectives were all potentially helpful... It can also depend on mutual understanding and respect: 'If you can look at the immediate thing, it might be that you've got different ideas but somewhere above that, the motivation 
might be common, where the aims overarch." "' (Priest et al., 2011) ${ }^{162}$.

[] Interagency "The high but inefficient use of the services of several agencies by patients... [contributes further to this lack of continuity, the diffused nature of the treatment being offered workingland by professionals, and responsibility for treatment." (Koekkoek et al., 2009) $)^{(53)}$ 国

[3 the wider "We get very little feedback from the talk therapies team as to how they felt things went. We obviously get the feedback oh they attended six out of the seven sessions or system [ you know, initially they seem very depressed, but you never get?a feedback as to how treatment is going. It's important I feel because if the service works closely with you it helps you to support the patient better. Added to which many of these patients have other health complaints and better communication can only lead to better treatment."国(French et al., 2019) $)^{(49)}$ 国

"Almost all groups of clinicians reported the need for more training in working with [persons? who have a personality disorder, particularly for generalist mental health workers and frontline and ancillary staff. Similarly, several groups of clinicians also emphasized the need for a coordinated and cross-agency approach to training, including staff from other government agencies that have more frequent contact with clients with personality disorders, such as social service organizations. This is in order to encourage an intensive and integrated case management approach (e.g. [' 'coordinated whole of team training', and 'cross-agency training within local areas: health, police, community mental health, custodial services, community services'). "回回

"Another theme that emerged was the need for better acknowledgement of the existence of personality disorder as a diagnostic group, and a recognition of the costs and time required to help these clients (e.g. 'acknowledge the disorder: it exists, is treatable, worthwhile, and economically good to treat', 'seeing treatment of personality disorder as core business, alongside mood and psychotic disorders', and 'recognition of the enormous cost of the disorder in terms of health service resources, clinician time, [and] administration')." [. (Fanaian et al., 2013) ${ }^{(48)}$ [?]

"Promoting the new service with the right balance of expertise and uncertainty or humility has been challenging. It was difficult to promote the setting up of a specialist service without implying that existing services had somehow failed this client group. It is important to not locate 'blame' in either the patient or the worker [who may naturally feel her / himself to be the brunt of criticism]. And it's a double-edged sword: they want to refer to you, but success is resented: you have to work with that." "⿴囗口 (Crawford et al., 2007) ${ }^{(46)}$ 回

[3] Establishing "Clinicians felt their confidence to recall theory and detail post training could fade, as they rolled on with daily case management activity." (Bosanac et al., 2015$)^{1433}$ (B)

[? new services, "Several administrators described the importance of ongoing training to accommodate staff turnover, exemplified by the administrator who said] 'There also is no provision interventions for training new people once the training is over. We don't like that [the trainers are] out after that instead of providing training on an ongoing basis."'](Herschell et al., and skills? 2009$\left.)^{(50)}\right)_{\text {国 }}$

回 回

"The respondents were asked to provide general feedback on how trainings?can address the challenges of implementing DBT mentioned above. Several respondents discussed the difficulties in establishing collaboration between teams at different agencies and viewed this collaboration as key to sustainability of their DBT program, due in part, to the changing of staffing and the loss of many team members due to financial cutbacks. "ㅁ. (Carmel et al., 2014) ${ }^{(44)}$ 回

[8] "Because of the fact the network was initially a pilot there was limited access to funding and resources and their capacity to coordinate care for?a large number of was restricted. It appeared to the referring bodies that the network was unable to cope with the scale of need."国(Hogard and Ellis, 2010) ${ }^{(51)}$ 边

[2] [T "Training alone was perceived as insufficient for practice, but a combination of training and hands-on experience was useful to build confidence. One participant stated 'that could perhaps be a good thing if it was-if everyone saw at least one person through it ... they felt comfortable in it, they felt that they could relax ... they could

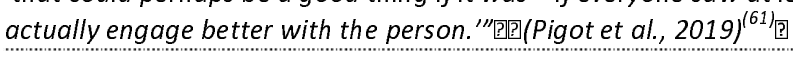

[3] "However, there were some clear areas in which the participants were less satisfied, for example, with the viability of post-training implementation of methods, most notably associated with a perception of an increased time pressure created by some of the practices suggested."[(Thompson et al., 2008) ${ }^{(67)}$ [ $]$ 
medRxiv preprint doi: https://doi.org/10.1101/2020.12.15.20248267; this version posted December 16, 2020. The copyright holder for this preprint (which was not certified by peer review) is the author/funder, who has granted medRxiv a license to display the preprint in perpetuity.

It is made available under a CC-BY-ND 4.0 International license .

\section{The use and misuse of diagnosis}

Our main aim was to synthesise evidence on clinician views of good practice, but it was clear that underlying beliefs about the nature of such difficulties and the appropriate use of diagnosis influenced clinicians' perspectives on care. A few studies reported that some clinicians found conceptualising and diagnosing difficulties as "personality disorder" helpful. They saw it as offering a 'common language', and a useful way to understand service users' difficulties, while also helping to ensure that service users were seen as having genuine needs.

However, across a number of studies, clinicians questioned the use, meaning and validity of this diagnosis. They saw it as being associated with stigma, discrimination and exclusion from services, felt it could be difficult to 'shake off', and risked becoming "the person's entirety"(47). Patients with a psychosis were seen as not accountable and in need of support. Borderline patients, however, were considered theatrical, posing, and in need of punishment.

Psychologist describing a crisis intervention team (Koekkoek et al., 2009) (53) $^{(2)}$ secondary care services suggested it was made at times on a basis of "gut instinct"(54) or "gut feeling ${ }^{\prime \prime(70)}$ or because other diagnoses did not 'fit'. An investigation of clinician views in generic community and voluntary sector services found that some perceived "personality disorder" as essentially "a form of social deviance or cultural rule-breaking"(64), while others felt that the label was an unhelpful medicalisation of legitimate feelings of distress, especially among women. In this study, as in several studies examining perspectives of specialist clinicians, a majority of clinicians saw trauma and adversity as major causes of "personality disorder". As a result of concerns about diagnosis, clinicians were reported in several studies to be reluctant to use this label and to avoid discussing it with service users. Some opted for alternative diagnoses (e.g., complex post-traumatic stress disorder) or employed what they considered to be 'euphemisms' like "difficulty managing 
medRxiv preprint doi: https://doi.org/10.1101/2020.12.15.20248267; this version posted December 16 , 2020. The copyright holder for this preprint (which was not certified by peer review) is the author/funder, who has granted medRxiv a license to display the preprint in perpetuity.

It is made available under a CC-BY-ND 4.0 International license .

224 emotions" ${ }^{\prime \prime 6)}$. Other specialist clinicians reported that they preferred a focus on narrative

225 descriptions of presenting difficulties rather than relying on a "personality disorder" diagnosis.

\section{The patient journey into services: nowhere to go}

Access to services for people with CEN was reported in several studies to be a persistent difficulty, with GPs in one study ${ }^{(49)}$ reporting longer waiting times than for any other group of mental health service users. Referrals for specialist support were impeded by factors such as a lack of local services, lack of awareness of services, frequent changes to services, and poorly established referral pathways. This was felt to risk disengagement, escalation of distress, or missing windows of opportunity to provide effective support.

Thresholds for acceptance by specialist services were reported in some studies to be inconsistent and influenced by subjective judgements regarding for example 'severity', 'stuck'ness or 'motivation to engage'. Many service users were excluded from specialist support due to being perceived as a risk to others (e.g., through having a forensic history), having substance misuse problems, exhibiting behaviour considered too 'problematic' or 'chaotic', or being seen as 'nonpsychologically minded'.

Referrers such as GPs in several studies also reported difficulties getting service users accepted by generic, mainstream community mental health teams or psychological treatment services. However, in other studies, clinicians working in these generic teams saw their eligibility criteria as over-inclusive, with one study describing them as a "dumping ground" for anyone who did not 'fit' elsewhere ${ }^{(62)}$. Stepped care pathways could also contribute to difficulties accessing appropriate treatment. For example, clinicians in the UK reported being encouraged to refer initially to primary care Improving Access to Psychological Therapy (IAPT) or mainstream secondary care services, rather than to specialist teams. However, knowledge and capacity for treating CEN were often seen as lacking in these generic services, with people with CEN not prioritised and clinicians feeling they did not have the skills to deliver expected care. Some referrers described 'embellishing' 
medRxiv preprint doi: https://doi.org/10.1101/2020.12.15.20248267; this version posted December 16, 2020. The copyright holder for this preprint (which was not certified by peer review) is the author/funder, who has granted medRxiv a license to display the preprint in perpetuity.

It is made available under a CC-BY-ND 4.0 International license .

referral information to meet thresholds for specialist support. However, in other cases, GPs as well as assessors in secondary care services, 'downplayed' service users' difficulties or risk levels and emphasised 'more agreeable' traits to meet thresholds for primary care support, such as IAPT services. Service users could end up being passed back and forth in "a tennis ball effect" ${ }^{\text {"(54) }}$ with a high but inefficient use of services.

You know if you mention 'PD' there will be nowhere at all for them to go so I'm usually very careful not to put it down in their notes. I usually say depressed or a bit anxious. Something that won't make them think the patient is risky. It's about knowing the hoops that you've got to jump through.

GP (French et al., 2019) $)^{(49)}$

The referral process was reported to be facilitated by good working relationships and communication between receiving clinicians and referrers, outreach by specialist services to raise visibility and explain service models, and acceptance of self-referrals, which some felt could be empowering and inclusive. Some referrers valued holistic, in-depth assessments and formulations from specialist clinicians, particularly non-medical, non-psychiatric or psychodynamic formulations, even if service users ultimately weren't taken on, as these could inform treatment plans and facilitate therapeutic relationships.

\section{Therapeutic relationships: connection and distance}

Strong, trusting relationships between clinicians and service users were seen as key to treatment success across many studies, but clinicians' experiences of such relationships varied greatly both between and within studies. In several studies, clinicians were keen to emphasise the positives of working with people with CEN, describing them as 'relatable', 'honest' and 'creative', and seeing the role of the clinician as being to "harness that"(37). However, negative feelings and a sense of burnout were also frequently described, with clinicians viewing (or reporting that other clinicians viewed) service users as 'demanding', 'challenging', 'risky', 'dependant', 'self-destructive', 
medRxiv preprint doi: https://doi.org/10.1101/2020.12.15.20248267; this version posted December 16, 2020. The copyright holder for this preprint (which was not certified by peer review) is the author/funder, who has granted medRxiv a license to display the preprint in perpetuity.

It is made available under a CC-BY-ND 4.0 International license .

274 'manipulative', 'non-compliant', 'untreatable', and likely to 'push boundaries'. Service users'

275 difficulties were seen as enduring but urgent, and clinicians could feel overwhelmed by "a

276 bottomless pool of need”(70) especially as comorbid diagnoses and wider social issues with housing,

277 employment, finances and social networks were often also present. Clinicians described feeling both

278 idealised by service users and as though nothing they did was good enough. While establishing an

279 authentic connection with service users was seen as vital, clinicians admitted to fears of being

280 "sucked dry" and "emotionally swamped"(63), experiencing feelings of vulnerability and of being

281 dangerously on the edge of losing their sense of self.

Participants spoke repeatedly about the need to maintain a psychological distance from clients in order to prevent themselves from becoming overwhelmed or burned out.

In a few studies, however, clinicians reported they felt able to make use of their unsettling

feelings to connect with service users' own feelings. Although there were exceptions, negative

Overall, the impression across studies was that clinicians described the need to be authentic, non-judgemental, empathic, collaborative, hopeful, motivating, consistent and dependable to build 
medRxiv preprint doi: https://doi.org/10.1101/2020.12.15.20248267; this version posted December 16, 2020. The copyright holder for this preprint (which was not certified by peer review) is the author/funder, who has granted medRxiv a license to display the preprint in perpetuity.

It is made available under a CC-BY-ND 4.0 International license .

299

300

301

302

303

304

well, clinicians described successfully negotiating connection and distance in the therapeutic relationship: being open, warm and available, but also retaining boundaries, structure and a degree of emotional detachment. Clinicians spoke of a need to create a sense of shared responsibility for progress with service users, and of the value of adopting a curious, non-expert stance to help develop a safe space where strong emotions could be processed, tolerated and "radically accepted $^{\prime(47)}$.

Clinicians who reported more positive relationships tended to be those who felt better supported, for example describing better team working, supervision, and informal support from their colleagues, as well as longer-term treatment frameworks, which allowed time for relationships to develop. Such support appeared to be much more available in more specialised services.

\section{The nature of treatment: not doing too much or too little}

Clinicians' beliefs regarding appropriate duration of treatment, and how best to negotiate not doing 'too much' or 'too little', were complex. There was consensus across studies that people with CEN had long-term needs, but in a few studies clinicians voiced concerns that open-ended, long-term support could be too demanding for service users to engage with, too resource-intensive, or could result in 'dependency' and a lack of delivery of interventions with clear therapeutic content, particularly in generic secondary care services. Clinicians felt that it was important to be realistic about what they could achieve and to avoid setting expectations that they could 'fix' everything. At the same time, in several studies clinicians emphasised that not offering sufficient long-term support could result in unrealistic expectations for recovery, disappointment and undertreatment. Several studies reported a perceived lack of well-developed, longer-term support programmes at a medium level of intensity. 
medRxiv preprint doi: https://doi.org/10.1101/2020.12.15.20248267; this version posted December 16, 2020. The copyright holder for this preprint (which was not certified by peer review) is the author/funder, who has granted medRxiv a license to display the preprint in perpetuity.

It is made available under a CC-BY-ND 4.0 International license .

322
The requirements of the system do not always fit with the needs of the people who are using the service: The expectation is that you will recover... you will get out of the service... we can only work with you for a certain amount of time... It just doesn't work as simply as that. Mainstream secondary care clinician (Priest et al., 2011) what could be achieved, managing the expectations of both clinicians and service users, and maintaining hope. In one study, clinicians saw a tendency in mainstream settings for clinicians to "do completely nothing ${ }^{\prime(53)}$ in therapeutic encounters with people with CEN, or alternatively to display 'false optimism' or 'therapeutic nihilism', rapidly discharging service users due to underlying feelings of powerless and demoralisation. Paradoxically, however, such undertreatment then had the effect of increasing the very 'dependency' clinicians feared, as service users had to keep 'coming back for more'.

Premature discharge was identified as common and was put down to clinicians seeking to 'escape' from work they found challenging, to service recovery models conflicting with service users' needs, and to pressures to move people on. Yet, there was consensus across several studies that discharge could be particularly challenging for people with CEN and needed to be managed sensitively, especially because of associated safety issues (e.g., due to service users feeling abandoned by clinicians). Views diverged, however, about the best way to approach discharge. For example, in one study evaluating specialist services for $\mathrm{CEN}^{(46)}$, some clinicians feared that openended service use without a clear plan for discharge could reduce service users' motivation to develop coping skills, affect the service's capacity to take on new referrals, and encourage 'dependency'. These clinicians felt having discharge or self-sufficiency as a time-specific goal from the beginning of care was helpful. However, other clinicians in the same study favoured offering continuing support at a lower level of intensity (for example through peer support), rather than 
medRxiv preprint doi: https://doi.org/10.1101/2020.12.15.20248267; this version posted December 16, 2020. The copyright holder for this preprint (which was not certified by peer review) is the author/funder, who has granted medRxiv a license to display the preprint in perpetuity.

It is made available under a CC-BY-ND 4.0 International license .

346 absolute discharge following a period of intensive treatment, with clear provisions for re-engaging

347 with services if required.

Short-term therapy, such as that offered by IAPT in the UK, tended to be seen as

349 insufficiently flexible and intensive for people with CEN. In one study, primary care clinicians

350 described a sense that they were "short-changing" service users ${ }^{(63)}$. In a few studies, clinicians also

351 expressed fears that short-term support could potentially be harmful or experienced by service users

352 as 'abandoning' and 'retraumatising'. However, in a small number of studies clinicians did argue that

353 short-term support had value, either at specific points in service users' treatment journeys, or for

354 those with less severe difficulties.

355 Clinicians in multiple studies also underlined the need to deliver both psychotherapeutic

356 interventions and pragmatic social support to meet the varied and fluctuating needs of this

357 population. Pragmatic support, which was reportedly offered more often in specialist services, could

358 include vocational, educational, social, substance misuse, or parenting support, as well as skills to

359 promote independence.

\section{Intervention models}

Specific treatment models that clinicians reported as having therapeutic benefits included

(CAT) and psychodynamic formulations. However, in several studies clinicians also emphasised that

'one size does not fit all', that diverse, flexible treatment options were needed within mental health than those based on diagnosis or driven by manuals.

There was a consensus across studies that a variety of approaches could be taken to some 
medRxiv preprint doi: https://doi.org/10.1101/2020.12.15.20248267; this version posted December 16, 2020. The copyright holder for this preprint (which was not certified by peer review) is the author/funder, who has granted medRxiv a license to display the preprint in perpetuity.

It is made available under a CC-BY-ND 4.0 International license .

370

371

372

373

374

375

prioritised interventions that promoted development of skills relating to emotion regulation, distress tolerance, or developing a capacity for thinking and feeling rather than doing. Similarly, models that helped service users to practice their interpersonal skills (e.g., via groups, peer support, or therapeutic communities) were seen as valuable in several studies. DBT was the specific therapeutic intervention most often discussed in studies and clinicians identified several benefits from this. As well as helping service users develop better relationships and emotion regulation, clinicians felt it was based on a clear model and manual, and that it promoted hope, decreased medication use, encouraged service users to take responsibility for treatment, and helped encourage compassion, understanding and team working on the part of clinicians. Clinicians in some studies did, however, also report that delivering DBT placed considerable demands on them and their services, including the need for intensive training, implementation of a complex model allowing relatively little flexibility, and being contactable outside of working hours.

Formats like groups, peer support, and therapeutic communities were also valued for broadening the range of available options and promoting collaborative, user-led models of care and empowering service users to have ownership over their treatment in a more democratic way. Finally, support for family and friends was identified in several studies as important but as an area where even well-resourced specialist services often fall short despite the perception that people with CEN often experience difficulties with relationships.

\section{Managing safety issues and crises: being measured and proactive}

Managing safety issues was considered vital across all treatment settings. The nature of deliberate self-harm and other safety issues in the context of CEN was seen as differing from acute presentations in other mental health conditions because of its chronic, recurrent and to some extent predictable nature. As such, clinicians felt it could be prepared for proactively, through open dialogue with service users to agree parameters within which clinicians would respond. 
medRxiv preprint doi: https://doi.org/10.1101/2020.12.15.20248267; this version posted December 16 , 2020. The copyright holder for this preprint (which was not certified by peer review) is the author/funder, who has granted medRxiv a license to display the preprint in perpetuity.

It is made available under a CC-BY-ND 4.0 International license .

In a small number of studies, clinicians suggested that 'rescuing' or stepping in too quickly at

times of crisis could be detrimental or disempowering for service users. However, there was a

competing need not to become neglectful, with a lack of consensus regarding how available

clinicians should make themselves. Views about out of hours service provision varied. In one study of

community-based mental health services implementing DBT, some clinicians described 24/7

availability or an 'on call' system as a 'step backwards' and ineffective. But in other studies clinicians

argued that this was important, and that greater availability of support in fact usually reduced the

need for it. Some clinicians felt that people with CEN were seen as 'bad' for posing a safety risk, in

contrast to those with other diagnoses, such as psychosis, who were seen as 'mad'.

Practice in mainstream services was described in some studies as risk-averse and reactive,

sometimes creating a vicious cycle wherein service users felt they had to present in crisis to get

more in put. Clinicians used to dealing with crises in the context of conditions such as depression or

psychosis were reported to struggle to manage the specific dynamics of safety concerns for people

with CEN. Specialist services were seen as adopting more proactive approaches, negotiating plans

for managing safety issues in collaboration with service users, moving away from action-reaction or

fearful responses from clinicians, and fostering ownership of the management of safety issues

among service users.

\section{Clinician needs}


medRxiv preprint doi: https://doi.org/10.1101/2020.12.15.20248267; this version posted December 16, 2020. The copyright holder for this preprint (which was not certified by peer review) is the author/funder, who has granted medRxiv a license to display the preprint in perpetuity.

It is made available under a CC-BY-ND 4.0 International license .

420 example, when clinicians described a need to reduce service users' alleged 'dependency' and

421 promote 'self-sufficiency', this seemed in part connected to clinicians' own feelings of being

422 overwhelmed, as well as to wider service pressures to conserve resources. One study of clinicians

423 working in "personality disorder" services ${ }^{(37)}$ suggested that service users' perceived difficulties (e.g.,

424 with reflection) could be 'mirrored' further up the organisation. This study also reported that service

425 leads across several teams appeared to be 'charismatic' but also 'autocratic', seeking to 'quell

426 dissent' among clinicians by adopting firm, unequivocal stances. In other studies, it was clear that

427 services, rather than service users, were at times experienced by clinicians as 'difficult to engage

428 with'.

It's not the patients that make you frustrated nowdays, it's the organization around that is troublesome.

The importance of clinicians feeling supported in their work was a common theme across

studies. Working effectively with people with CEN without becoming burnt out was seen as

achievable, but the organisational support needed to do so was often missing, with the low priority

and investment accorded to treatment of people with CEN affecting both service users and

clinicians. Clinicians valued both supportive relationships with colleagues and formal supervision in a

variety of formats, including individual and whole team supervision and input from external experts.

438 The importance of addressing clinicians' own emotional needs, engaging in reflective practice and

but provision was frequently described as inadequate. 
medRxiv preprint doi: https://doi.org/10.1101/2020.12.15.20248267; this version posted December 16 , 2020. The copyright holder for this preprint (which was not certified by peer review) is the author/funder, who has granted medRxiv a license to display the preprint in perpetuity.

It is made available under a CC-BY-ND 4.0 International license .

445 somebody"(63). There could also be challenges in teams where only one or two clinicians in a team

446 were trained in a particular therapeutic intervention or skill set. While clinicians saw value in

447 including a range of clinicians with diverse backgrounds and approaches they also felt this could

448 encourage "splitting", making it more difficult to develop a shared language or model of

449 understanding across team members.

Having divided caseloads (i.e., not fully CEN) was considered by some to be beneficial for

integration of CEN work into generic teams and for staff wellbeing. However, having competing

452 clinical priorities could impede therapeutic work, and the 'psychological shift' between various roles

453 was experienced by some as challenging. One study noted that specialist services tended to promote

454 broad, combined roles where all clinicians contributed to delivering the therapeutic model, but this

455 required significant training. Specialist services sometimes had 'flat hierarchies' which could be

456 empowering but also frustrating for clinicians when responsibility was equal but authority or pay, for

457 example, was not.

458 Interagency working and the wider system

Effective inter-team and inter-agency working was considered important for management of

460 the resource-intensive, multi-agency, and often out-of-hours service use by people with CEN.

461 However, reports of inadequate communication between services were common at all levels of

462 care. Challenges included high staff turnover, staff cutbacks due to reduced budgets, time

463 constraints, and disagreements between clinicians or competing priorities, with poor interagency

464 working leaving clinicians feeling more anxious and less contained. Pre-existing, personal, or good

465 professional relationships and clearly assigned responsibilities (taking into account service user

466 preferences regarding clinicians and services where possible) facilitated interagency working.

Clinicians in mainstream services reported in several studies that they valued support from 
medRxiv preprint doi: https://doi.org/10.1101/2020.12.15.20248267; this version posted December 16, 2020. The copyright holder for this preprint (which was not certified by peer review) is the author/funder, who has granted medRxiv a license to display the preprint in perpetuity.

It is made available under a CC-BY-ND 4.0 International license .

470 was perceived as making efficient use of specialist staff, allowing them to support not only those on

471 their small caseload for intensive therapy but also a much wider group beyond the dedicated

472 services. However, reservations about such models were described in a few studies, including that

473 specialist input from specialists could undermine professional roles in mainstream service, may be

474 ineffective on an ad hoc rather than sustained basis, and risks specialist clinicians having

475 unsustainable workloads. There were also some tensions identified between mainstream and

476 specialist services, where mainstream services were seen as having to 'firefight' whereas specialist

477 services were perceived to have greater freedom to 'select' service users, refuse certain

478 responsibilities, and prioritise time for reflection.

\section{Establishing new services, interventions and skills}

Finally, a number of studies were conducted in the context of establishing a new service or

intervention programme, and thus themes emerged relating to good practice in initial

implementation. Factors that were considered helpful for developing new services or interventions

included: managerial support, recruitment of appropriate staff, leadership that embraced

uncertainty and allowed clinicians freedom to innovate, team building, cross-agency and whole team

training, and having realistic plans, timescales and budgets. Ongoing sustainability of new services

was facilitated by integrating them into existing service systems, effective interagency working, and

measuring and demonstrating good outcomes. Clinicians trained in new models described feeling

like 'beginners' despite their clinical expertise, and being required to make significant time

commitments for implementation and ongoing practice and learning. There was widespread 
medRxiv preprint doi: https://doi.org/10.1101/2020.12.15.20248267; this version posted December 16, 2020. The copyright holder for this preprint (which was not certified by peer review) is the author/funder, who has granted medRxiv a license to display the preprint in perpetuity.

It is made available under a CC-BY-ND 4.0 International license .

\section{Discussion}

495 Several overall proposals can be drawn from this synthesis of clinicians' perspectives for

496 good practice in treating this population effectively and respectfully and at the same time supporting

497 the clinicians working with them. Areas of consensus between the findings of eligible studies

498 included the need for high quality, holistic assessments and care plans encompassing physical,

499 psychological and social needs; easily navigable referral systems enabling good continuity of care;

500 and the need for a proactive, collaborative approach to safety management. Therapeutic

501 relationships were seen as key and as a major common factor in the success of different approaches,

502 and clinicians in participating studies believed that they could be improved through greater

503 therapeutic optimism, overcoming pejorative attitudes, developing partnerships between service

504 users and clinicians through shared responsibility and decision making, radical acceptance and a

505 non-expert stance, and sustainable models for service user involvement in care.

Some dilemmas and variations in opinion were also identified, especially regarding the

507 balance between doing 'too much' or 'too little.' Potential positive and negative consequences were

508 identified both for open-ended long-term input and for time-limited input, as for 24 hour availability

509 of clinicians in specialist services. Those who advocate for long-term support may be more in tune

510 with service users, reported often to see periods of treatment as too short and continuing support

511 between periods of intensive therapy as lacking ${ }^{(38)}$. Whether or not services were time-limited, there

512 was agreement that careful collaborative discharge planning was required to mitigate some of the

513 frequently experienced challenges and help service users work towards self-sufficiency.

Many of these findings align with those identified in our accompanying meta-synthesis of

515 the of the perspectives and experiences of service users with $\mathrm{CEN}^{(38)}$. For example, service users also

516 appear to prioritise individualised care, preferring clinicians to focus on individual needs and

517 aspirations rather than diagnosis or intervention fidelity. Clinicians were called upon in papers on

518 service user perspectives to sustain hope and provide encouragement while at the same time 
medRxiv preprint doi: https://doi.org/10.1101/2020.12.15.20248267; this version posted December 16, 2020. The copyright holder for this preprint (which was not certified by peer review) is the author/funder, who has granted medRxiv a license to display the preprint in perpetuity.

It is made available under a CC-BY-ND 4.0 International license .

519

520

521

522

523

524

maintaining realistic expectations and not invalidating service user distress. The centrality of the therapeutic relationship is a further point of consensus. While both clinicians and service users emphasised the need to offer a variety of treatment options to meet service users' heterogeneous needs, service users also prioritised structure, stability and a long-term perspective in their care. These are not inconsistent demands as options can be flexible and varied, yet the delivery of such can remain structured and consistent on an individual level.

Concerns around the usefulness and impact of using "personality disorder" labels were also similar to those reported from studies of service user perspectives. However, the included papers on clinician perspectives tended less to reflect recent calls by service user advocates and some clinicians, supported by patient testimonials and growing evidence, to give trauma a central role in the assessment and treatment of $\mathrm{CEN}^{(71,72)}$, a call also reinforced by feminist critiques of "personality disorder" as a mechanism for pathologising understandable responses to oppression, abuse and structural inequalities ${ }^{(17)}$. This omission may in part reflect the fact that most studies were conducted before the rise of the 'Trauma not PD' movement ${ }^{(71,72)}$. We suggest that alongside the priorities identified above, incorporating trauma-informed approaches to care and preventing retraumatisation within mental health settings should probably be seen as key elements in good practice if a shared agenda for service improvement is to be agreed on by service users and clinicians $^{(73)}$.

The value of exploring clinician perspectives is particularly in identifying ways of promoting positive change and of removing clinician-related barriers to this. This review echoes much other literature in identifying pejorative clinician attitudes and behaviours as an important obstacle to delivering care that is even adequate, especially in non-specialist settings. Developing and evaluating ways to challenge and change such behaviours is thus a pressing need. This review also identifies the need to extend more support to clinicians working with people with CEN; across several studies clinicians reported on the significant emotional toll of their work, which could potentially fuel 
medRxiv preprint doi: https://doi.org/10.1101/2020.12.15.20248267; this version posted December 16, 2020. The copyright holder for this preprint (which was not certified by peer review) is the author/funder, who has granted medRxiv a license to display the preprint in perpetuity.

It is made available under a CC-BY-ND 4.0 International license .

544 negative behaviours and a lack of therapeutic optimism. Several of our themes related to the need

545 for clinicians to strike a balance, including balancing connection against distance, doing too much or

546 too little in terms of treatment provision and balancing service user empowerment and

547 independence with service pressures of risk-aversion. Needs of different stakeholders also require

548 balancing: for example, do some clinicians warn against long-term input for the benefit of service

549 users (to promote independence), for the benefit of themselves (to avoid challenging work), or for

550 the benefit of services (to meet capacity constraints)? This balancing act, together with caseload and

551 referral pressures, may well contribute to the emotional toll of working with people with CEN.

552 However, clinicians, especially in specialist services, also described many ways of alleviating this

553 burden, including through supervision, reflective practice and informal support between colleagues.

554 The burdens associated with difficult therapeutic decisions, especially regarding safety, were clearly

555 alleviated by being shared, both with colleagues and service users. As such, multidisciplinary co-

556 produced formulations, maintaining the centrality of the therapeutic relationship, and 'holding in

557 mind' the SU could provide some guiding principles for clinicians when navigating these complex

558 balances and would be a useful focus for further research.

Constraints on good practice relating to the wider service system were recurrently

described, including exclusive thresholds and referral pathways, inflexibility of services to meet

diverse and long-term needs and manage co-occurring conditions, and lack of time for reflection and

training. Lack of recognition of the needs of people with CEN and lack of resourcing to meet these

needs were widely reported and likely to contribute. These deficits may also reflect a lack of

evidence and strategic thinking on how to optimise service design to result in coherent pathways

allowing smooth transitions between accessible services corresponding to service users' needs and 
medRxiv preprint doi: https://doi.org/10.1101/2020.12.15.20248267; this version posted December 16, 2020. The copyright holder for this preprint (which was not certified by peer review) is the author/funder, who has granted medRxiv a license to display the preprint in perpetuity.

It is made available under a CC-BY-ND 4.0 International license .

569 how to design systems of care that meet the varying needs of diverse service users at different

570 stages in their pathways through services now appears to be an important need.

\section{Limitations}

572 We aimed to include papers regarding management in the community of people with a

573 range of "personality disorder" diagnoses or who might have related difficulties, such as recurrent

574 self-harm, but not have received such a diagnosis. However, in practice most studies focused on

575 people who had received a diagnosis of "borderline personality disorder". As such, our findings

576 relate mainly to this group, with some heterogeneity in the ways in which study samples were

577 identified. There was a good variety of professional backgrounds and levels of care across included

578 papers, but little literature about voluntary organisations and other community services outside the

579 secondary mental health care system. This may reflect limitations of the search strategy, but

580 probably also indicates a scarcity of research in these areas. This may mean that the voices of staff

581 who support individuals who have disengaged or been excluded from the mainstream mental health

582 system are not included.

As this is a meta-synthesis identifying and cross-validating over-arching themes across many

584 studies, a level of nuance and specificity will have inevitably been lost, with findings pooled from a

variety of contexts, dates and countries. The two researchers who worked the most closely on

synthesis (JT and BLT) both have clinical experience of providing mental health care, while three

other authors (JR, TJ, EB) bring relevant lived experience of service use - the results presented here

and their interpretation may well be shaped by their perceptions born from these experiences.

Efforts were made to counter this through adopting an inductive approach to analysis, double coding review team and experts by experience and occupation. 
medRxiv preprint doi: https://doi.org/10.1101/2020.12.15.20248267; this version posted December 16 , 2020. The copyright holder for this preprint (which was not certified by peer review) is the author/funder, who has granted medRxiv a license to display the preprint in perpetuity.

It is made available under a CC-BY-ND 4.0 International license .

\section{Conclusion}

593 Clinicians' experiences of and perspectives on good practice for providing community care

594 for people with CEN offer valuable insight into how to better meet the needs of this population and

595 the needs of the clinicians supporting them and are largely in harmony with the perspectives of

596 service users ${ }^{(38)}$. In further research, a focus is now needed on how to implement these principles of

597 good practice across the service system to improve service user outcomes and the experiences of

598 service users and clinicians. Previous research has tended to focus on individual psychological

599 interventions: a focus on designing a whole system of care that can meet the longer-term needs of

600 people with CEN in a sustainable way is now desirable. Development and evaluation of fidelity

601 measures that reflect agreed good practice ${ }^{(74,75)}$, and of approaches to support services in achieving

602 and maintaining high fidelity, is a potential approach to meeting this need. The apparent congruence

603 on many values and principles between service users and clinicians suggests that a co-produced

604 approach to future research, service development and policy formulation is likely to be fruitful.

605 Finally, an overarching emerging issue deserving further research and policy development is of

606 equity: clinicians echo service users in arguing that people with CEN tend to be a marginal group,

607 often not prioritised for resources and attracting negative attitudes and behaviour. Change is not

likely to be achieved unless the needs of people with CEN are placed on an equal footing with the needs of people with other long-term physical and mental health conditions.

\section{Lived Experience Commentaries}

In line with service user critiques and our own lived experience, this meta-synthesis provides

further evidence that for many people with CEN, current mental health services are simply not fit for service cannot meet service users' needs, the signs of a system at breaking point are undeniable. 
medRxiv preprint doi: https://doi.org/10.1101/2020.12.15.20248267; this version posted December 16, 2020. The copyright holder for this preprint (which was not certified by peer review) is the author/funder, who has granted medRxiv a license to display the preprint in perpetuity.

It is made available under a CC-BY-ND 4.0 International license .

617 question: why do most services still regard the medical model as the panacea? It appears that we need major systemic change and services should truly embrace inclusive, co-designed approaches that value lived experience and also support user-led models of care. the urgent need to address this controversial terminology. no mention of the overlap with Autism Spectrum Conditions (ASC) ${ }^{(76)}$ and the fact that women are conversely under-diagnosed with ASC. This may have serious implications for potentially misdiagnosed service users who may end up trapped on unsuitable treatment pathways and therefore constitutes a significant gap in the evidence base warranting investment in further research. at meaningful recovery. answer to "Whose needs are they anyway?" should be a resounding "Everyone's!" 
medRxiv preprint doi: https://doi.org/10.1101/2020.12.15.20248267; this version posted December 16, 2020. The copyright holder for this preprint (which was not certified by peer review) is the author/funder, who has granted medRxiv a license to display the preprint in perpetuity.

It is made available under a CC-BY-ND 4.0 International license .

641 prevailing systemic flaws are not conducive to either individual practitioner or service improvement.

642 Likewise, influencing those clinicians who are steadfast in holding onto stigmatising views of people

643 with CEN is going to be a major challenge that should ideally be addressed with co-production

644 throughout service development and delivery.

Eva Broeckelmann and Jessica Russell

646

\section{Broken Mirrors}

Whilst reading this review, I was struck by the allegory of a mirror. The focus is on clinicians, but its sister paper with a service user focus ${ }^{(38)}$ reflects the same issues. The mirror allegory goes beyond similar themes being reflected. The opinions of each side are fragmented - like a broken mirror. The broken fragments of each side appear as perfect replicas of the other, yet can only see each other in reverse, appearing as polar opposites.

reporting this. This data is limited in providing an understanding of why, despite appearing to want the same thing, there is such a relational divide between service user and service provider.

The roles of people working within the Lived Experience Professions (i.e., peer support workers, service user consultants, lived experience researchers) could be described as roles that bridge between the two polarised worlds, communicating sameness and difference between the two. Literature exploring how this could relate to developing relational bridges within the field of trauma/complex emotional needs/"personality disorder" is not included - potentially because it does not exist or exists in a format that does not fit within the search criteria. This highlights the importance of being able to value experiential data as a valid consideration within research, in order to lessen the phenomenon of studies giving a perfect view of one small fragment of the broken mirror, whilst disregarding the rest. Services benefit more from a full view of the broken mirror, even if the individual shards are more blurred than one perfect piece. 
medRxiv preprint doi: https://doi.org/10.1101/2020.12.15.20248267; this version posted December 16, 2020. The copyright holder for this preprint (which was not certified by peer review) is the author/funder, who has granted medRxiv a license to display the preprint in perpetuity.

It is made available under a CC-BY-ND 4.0 International license .

665

This gave me pause for thought when researchers described their experiences of working in

666 services as a potential limitation in the review. Once they have acknowledged their own perspective,

667 understanding the line between this and the data, their 'limitation' is in fact a strength - and this

668 knowledge needs to be recognised, valued and encouraged more. The literature we use to inform 669 and shape policy is not being practiced under lab conditions, but in the messy world where broken 670 mirrors exist. 
medRxiv preprint doi: https://doi.org/10.1101/2020.12.15.20248267; this version posted December 16, 2020. The copyright holder for this preprint (which was not certified by peer review) is the author/funder, who has granted medRxiv a license to display the preprint in perpetuity.

It is made available under a CC-BY-ND 4.0 International license .

\section{Acknowledgments}

673 This report is based on independent research commissioned and funded by the National

674 Institute for Health Research Policy Research Programme. The views expressed are those of the

675 author(s) and not necessarily those of the NHS, the National Institute for Health Research, the

676 Department of Health and Social Care or its arm's length bodies, and other Government

677 Departments.

\section{Contributions}

679 Conceptualisation: Sonia Johnson, Sian Oram, Chris Cooper

680 Data curation: Chris Cooper, Luke Sheridan Rains, Jordan Troup, Zainab Dedat, Thomas Steare.

681 Formal analysis: Billie Lever-Taylor and Jordan Troup.

682 Methodology: Sonia Johnson, Sian Oram, Chris Cooper, Luke Sheridan Rains, Billie Lever-Taylor, and 683 Jordan Troup.

684 Supervision: Chris Cooper, Billie Lever-Taylor, Luke Sheridan Rains, Sian Oram, and Sonia Johnson.

685 Writing - original draft: Billie Lever-Taylor, Jordan Troup, Jessica Russell, Tamar Jeynes, and 686 Eva Broeckelmann.

687 Writing - review \& editing: Luke Sheridan Rains, Eva Broeckelmann, Tamar Jeynes, Jessica Russell,

688 Billie Lever-Taylor, Chris Cooper, Sian Oram, Oliver Dale, Shirley McNicholas, and Sonia Johnson

\section{Funding}

690 This paper presents independent research commissioned and funded by the National 691 Institute for Health Research (NIHR) Policy Research Programme, conducted by the NIHR Policy 692 Research Unit (PRU) in Mental Health. The views expressed are those of the authors and not 693 necessarily those of the NIHR, the Department of Health and Social Care or its arm's length bodies, 694 or other government departments. 


\section{References}

696 1. Winsper C, Bilgin A, Thompson A, Marwaha S, Chanen AM, Singh SP, et al. The prevalence of 697 personality disorders in the community: a global systematic review and meta-analysis. $\mathrm{Br} J$ 698 Psychiatry. 2020;216(2):69-78.

699 2. Beckwith H, Moran P, Reilly J. Personality disorder prevalence in psychiatric outpatients: a 700 systematic literature review. Personal Ment Health. 2014;8(2):91-101.

701 3. Coid J, Yang M, Bebbington P, Moran P, Brugha T, Jenkins R, et al. Borderline personality 702 disorder: health service use and social functioning among a national household population. Psychol 703 Med. 2009;39(10):1721-31.

704 4. Lenzenweger MF, Lane MC, Loranger AW, Kessler RC. DSM-IV Personality Disorders in the 705 National Comorbidity Survey Replication. Biological Psychiatry. 2007;62 (6):553-64.

706 5. Fok ML-Y, Stewart R, Hayes RD, Moran P. The impact of co-morbid personality disorder on 707 use of psychiatric services and involuntary hospitalization in people with severe mental illness. 708 2014;49(10):1631-40.

709 6. Newton-Howes G, Tyrer P, Johnson T. Personality disorder and the outcome of depression: 710 Meta-analysis of published studies. British Journal of Psychiatry. 2006;188(1):13-20.

$7117 . \quad$ Lee HB, Bienvenu O, Cho S, Ramsey C, Bandeen-Roche K, Eaton W, et al. Personality 712 disorders and traits as predictors of incident cardiovascular disease: findings from the 23-year 713 follow-up of the Baltimore ECA study. 2010;58(4):289-96.

714 8. Moran P, Stewart R, Brugha T, Bebbington P, Bhugra D, Jenkins R, et al. Personality disorder 715 and cardiovascular disease: Results from a national household survey. The Journal of Clinical 716 Psychiatry. 2007;68(1):69-74.

717 9. Quirk SE, El-Gabalawy R, Brennan S, Bolton J, Sareen J, Berk M, et al. Personality disorders 718 and physical comorbidities in adults from the United States: data from the National Epidemiologic 719 Survey on Alcohol and Related Conditions. Soc Psychiatry Psychiatr Epidemiol. 2014;50(5):807-20.

720 10. Fok ML-Y, Hayes RD, Chang C-K, Stewart R, Callard FJ, Moran P. Life expectancy at birth and all-cause mortality among people with personality disorder. J Psychosom Res. 2012;73(2):104-7. 11. Soeteman DI, Verheul R, Busschbach JJ. The burden of disease in personality disorders: diagnosis-specific quality of life. J Pers Disord. 2008;22(3):259-68.

12. McCrone PR, Dhanasiri S, Patel A, Knapp M, Lawton-Smith S. Paying the price: the cost of mental health care in England to 2026. London: King's Fund; 2008.

13. Soeteman DI, Hakkaart-van Roijen L, Verheul R, Busschbach JJ. The economic burden of personality disorders in mental health care. J Clin Psychiatry. 2008;69(2):259-65.

14. Campbell K, Clarke K-A, Massey D, Lakeman R. Borderline Personality Disorder: To diagnose or not to diagnose? That is the question. International journal of mental health nursing [Internet]. 2020. DOI: $10.1080 / 01612840.2020 .1833119$

15. Lester R, Prescott L, McCormack M, Sampson M, North West Boroughs Healthcare NHS Foundation Trust. Service users' experiences of receiving a diagnosis of borderline personality disorder: A systematic review. Personality and Mental Health. 2020;14(3):263-83.

16. Recovery in the Bin. RITB Position Statement On Borderline Personality Disorder. 2019. Available from: https://recoveryinthebin.org/2019/04/03/ritb-position-statement-on-borderlinepersonality-disorder/.

17. The Lancet Psychiatry. Beyond the borderline. The Lancet Psychiatry. 2019;6(3):187. 18. Dale O, Sethi F, Stanton C, Evans S, Barnicot K, Sedgwick R, et al. Personality disorder services in England: findings from a national survey. BJPsych Bull. 2017;41(5):247-53.

19. National Institute for Mental Health for England. Personality Disorder: No Longer a Diagnosis of Exclusion. Policy Implementation Guidance for the Development of Services for People with Personality Disorder. London: NIMH(E); 2003.

20. Snowden P, Kane E. Personality disorder: no longer a diagnosis of exclusion. Psychiatric Bulletin. 2003;27(11):401-3. 
745 21. NHS England. NHS Mental Health Implementation Plan 2019/20 - 2023/24. England: NHS

746 England; 2019.

747 22. Royal College of Psychiatrists PS01/20. Services for people diagnosable with personality

748 disorder 2020. Available from: https://www.rcpsych.ac.uk/docs/default-source/improving-

749 care/better-mh-policy/position-statements/ps01 20.pdf?sfursn=85af7fbc 2.

750 23. Jarrett C. Understanding personality disorder. The Psychologist. 2006;19(7):402.

751 24. Chanen A, Sharp C, Hoffman P, Global Alliance for Prevention and Early Intervention for

752 Borderline Personality Disorder. Prevention and early intervention for borderline personality

753 disorder: a novel public health priority. World Psychiatry. 2017;16(2):215-6.

754 25. Simonsen S, Bateman A, Bohus M, Dalewijk HJ, Doering S, Kaera A, et al. European guidelines

755 for personality disorders: past, present and future. Borderline Personality Disorder and Emotion

756 Dysregulation. 2019;6(1):9.

757 26. National Health and Medical Research Council. Clinical Practice Guideline for the

758 Management of Borderline Personality Disorder. Melbourne: National Health and Medical Research

759 Council; 2012.

760 27. Blum N, St. John D, Pfohl B, Stuart S, McCormick B, Allen J, et al. Systems Training for

761 Emotional Predictability and Problem Solving (STEPPS) for Outpatients With Borderline Personality

762 Disorder: A Randomized Controlled Trial and 1-Year Follow-Up. American Journal of Psychiatry.

763 2008;165(4):468-78.

764 28. Clarkin JF, Levy KN, Lenzenweger MF, Kernberg OF. Evaluating Three Treatments for

765 Borderline Personality Disorder: A Multiwave Study. American Journal of Psychiatry.

766 2007;164(6):922-8.

767 29. Giesen-Bloo J, van Dyck R, Spinhoven P, van Tilburg W, Dirksen C, van Asselt T, et al.

768 Outpatient Psychotherapy for Borderline Personality Disorder: Randomized Trial of Schema-Focused

769 Therapy vs Transference-Focused Psychotherapy. Archives of General Psychiatry. 2006;63(6):649-58.

770

771

772 al. Psychological therapies for people with borderline personality disorder. Cochrane Database of Systematic Reviews [Internet]. 2020; (5):CD012955. DOI: 10.1002/14651858.CD012955.pub2 33. Evans S, Sethi F, Dale O, Stanton C, Sedgwick R, Doran M, et al. Personality disorder service provision: a review of the recent literature. Mental Health Review Journal. 2017;22(2):65-82.

34. Crawford M, Price K, Rutter D, Moran P, Tyrer P, Bateman A, et al. Dedicated communitybased services for adults with personality disorder: Delphi study. Br J Psychiatry. 2008;193(4):342-3. 35. Ring D, Lawn SA-O. Stigma perpetuation at the interface of mental health care: a review to compare patient and clinician perspectives of stigma and borderline personality disorder[Internet]. 2019. DOI: 10.1080/09638237.2019.1581337.

36. Dickens GL, Lamont E, Gray S. Mental health nurses' attitudes, behaviour, experience and knowledge regarding adults with a diagnosis of borderline personality disorder: systematic, integrative literature review. Journal of Clinical Nursing. 2016;25:1848-75.

37. Crawford MJ, Adedeji T, Price K, Rutter D. Job Satisfaction and Burnout Among Staff Working in Community-Based Personality Disorder Services. International Journal of Social Psychiatry. 2010;56(2):196-206. 
794 38. Sheridan Rains L, Echave A, Rees J, Scott HR, Lever-Taylor B, Broeckelmann E, et al. Service 795 user experiences of community services for Complex Emotional Needs: A qualitative thematic 796 synthesis (pre-print). medRxiv [Internet]. 2020. DOI: 10.1101/2020.10.30.20222729

797 39. Botham J, Clark A, Steare T, Stuart R, Oram S, Lloyd-Evans B, et al. Community interventions

798 for people with complex emotional needs that meet the criteria for 'personality disorder' diagnoses:

799 a systematic review of economic evaluations (pre-print). medRxiv [Internet]. 2020. DOI:

$800 \quad 10.1101 / 2020.11 .03 .20225078$

801 40. Moher D, Shamseer L, Clarke M, Ghersi D, Liberati A, Petticrew M, et al. Preferred reporting

802 items for systematic review and meta-analysis protocols (PRISMA-P) 2015 statement. Systematic

803 Reviews. 2015;4(1):1.

804 41. Thomas J, Harden A. Methods for the thematic synthesis of qualitative research in 805 systematic reviews. BMC Medical Research Methodology. 2008;8(1):45.

806 42. Critical Appraisal Skills Programme. CASP Qualitative Checklist 2018. Available from: https://casp-uk.net/wp-content/uploads/2018/01/CASP-Qualitative-Checklist-2018.pdf

43. Bosanac $P$, Hamilton B, Beatson J, Trett R, Rao S, Mancuso S, et al. Mentalization-based intervention to recurrent acute presentations and self-harm in a community mental health service setting. Australasian Psychiatry. 2015;23(3):277-81.

44. Carmel A, Rose ML, Fruzzetti AE. Barriers and solutions to implementing dialectical behavior therapy in a public behavioral health system. Adm Policy Ment Health. 2014;41(5):608-14.

45. Crawford M, Rutter D. Lessons Learned from an Evaluation of Dedicated Community-based Services for People with Personality Disorder. The Mental Health Review. 2007;12(4):55-61.

46. Crawford M, Rutter D, Price K, Weaver T, Josson M, Tyrer P, et al. Learning the lessons: a multi-method evaluation of dedicated community-based services for people with personality disorder. London: National Co-ordinating Centre for NHS Service Delivery \& Organisation. 2007. 47. Donald F, Duff C, Lawrence K, Broadbear J, Rao S. Clinician perspectives on recovery and borderline personality disorder. The Journal of Mental Health Training, Education and Practice. 2017;12(3):199-209.

48. Fanaian M, Lewis KL, Grenyer BFS. Improving services for people with personality disorders: Views of experienced clinicians. International Journal of Mental Health Nursing. 2013;22(5):465-71. 49. French L, Moran P, Wiles N, Kessler D, Turner KM. GPs' views and experiences of managing patients with personality disorder: a qualitative interview study. BMJ Open [Internet]. 2019; 9(2):e026616. DOI: 10.1136/bmjopen-2018-026616

50. Herschell AD, Kogan JN, Celedonia KL, Gavin JG, Stein BD. Understanding Community Mental Health Administrators' Perspectives on Dialectical Behavior Therapy Implementation. Psychiatric Services. 2009;60(7):989-92.

51. Hogard E, Ellis R. An evaluation of a managed clinical network for personality disorder: breaking new ground or top dressing? Journal of Evaluation in Clinical Practice. 2010;16(6):1147-56. 52. Hutton R, Hodge S, Tighe M. Switching roles: a qualitative study of staff experiences of being dialectical behaviour therapists within the National Health Service in England. The Cognitive Behaviour Therapist [Internet]. 2017; 10:e6. DOI: 10.1017/S1754470X17000083

53. Koekkoek B, van Meijel B, Schene A, Hutschemaekers G. Clinical Problems in Community Mental Health Care for Patients with Severe Borderline Personality Disorder. Community Mental Health Journal. 2009;45(6):508.

54. Lamph G, Baker J, Dickinson T, Lovell K. Personality disorder co-morbidity in primary care 'Improving Access to Psychological Therapy' services: A qualitative study exploring professionals' perspectives of working with this patient group. Personality and Mental Health. 2019;13(3):168-79. 55. Langley GC, Klopper $\mathrm{H}$. Trust as a foundation for the therapeutic intervention for patients with borderline personality disorder. Journal of Psychiatric and Mental Health Nursing. 2005;12(1):23-32. 
845 57. Morant N, King J. A multi-perspective evaluation of a specialist outpatient service for people 846 with personality disorders. The Journal of Forensic Psychiatry \& Psychology. 2003;14(1):44-66.

847 58. O'Connell B, Dowling M. Community psychiatric nurses' experiences of caring for clients with 848 borderline personality disorder. Mental Health Practice. 2013;17(4):27-33.

849 59. Perseius KI, Kåver A, Ekdahl S, Åsberg M, Samuelsson M. Stress and burnout in psychiatric 850 professionals when starting to use dialectical behavioural therapy in the work with young self-

851 harming women showing borderline personality symptoms. Journal of Psychiatric and Mental Health 852 Nursing. 2007;14(7):635-43.

853 60. Perseius K-I, Öjehagen A, Ekdahl S, Åsberg M, Samuelsson M. Treatment of suicidal and 854 deliberate self-harming patients with borderline personality disorder using dialectical behavioral 855 therapy: the patients' and the therapists' perceptions. Archives of Psychiatric Nursing.

856 2003;17(5):218-27.

857 61. Pigot M, Miller CE, Brockman R, Grenyer BFS. Barriers and facilitators to the implementation 858 of a stepped care intervention for personality disorder in mental health services. Personality and 859 Mental Health. 2019;13(4):230-8.

860 62. Priest P, Dunn C, Hackett J, Wills K. How can mental health professionals best be supported 861 in working with people who experience significant distress? Journal of Mental Health [Internet]. 862 2011; 20(6):543-54 pp.]. DOI: 10.3109/09638237.2011.577115

863 63. Rizq R. 'There's always this sense of failure': an interpretative phenomenological analysis of 864 primary care counsellors' experiences of working with the borderline client. Journal of Social Work 865 Practice. 2012;26(1):31-54.

866 64. Stalker K, Ferguson I, Barclay A. 'It is a horrible term for someone': service user and provider perspectives on 'personality disorder'. Disability \& Society. 2005;20(4):359-73.

65. Stroud J, Parsons R. Working with borderline personality disorder: A small-scale qualitative investigation into community psychiatric nurses' constructs of borderline personality disorder. Personality and Mental Health. 2013;7(3):242-53.

66. Sulzer SH, Muenchow E, Potvin A, Harris J, Gigot G. Improving patient-centered communication of the borderline personality disorder diagnosis. Journal of Mental Health. 2016;25(1):5-9.

874 67. Thompson AR, Donnison J, Warnock-Parkes E, Turpin G, Turner J, Kerr IB. Multidisciplinary community mental health team staff's experience of a 'skills level' training course in cognitive analytic therapy. International Journal of Mental Health Nursing. 2008;17(2):131-7.

68. Vyas A, Spain C, Rawlinson D. Working in a therapeutic community: exploring the impact on staff. Therapeutic Communities: The International Journal of Therapeutic Communities. 2017;38(1):32-40.

69. Wilson R, Weaver T, Michelson D, Day C. Experiences of parenting and clinical intervention for mothers affected by personality disorder: a pilot qualitative study combining parent and clinician perspectives. BMC Psychiatry. 2018;18(1):152.

70. Wlodarczyk J, Lawn S, Powell K, Crawford GB, McMahon J, Burke J, et al. Exploring General Practitioners' Views and Experiences of Providing Care to People with Borderline Personality Disorder in Primary Care: A Qualitative Study in Australia. International Journal of Environmental Research and Public Health. 2018;15(12):2763.

71. Giourou E, Skokou M, Andrew SP, Alexopoulou K, Gourzis P, Jelastopulu E. Complex posttraumatic stress disorder: The need to consolidate a distinct clinical syndrome or to reevaluate features of psychiatric disorders following interpersonal trauma? World J Psychiatry. 2018;8(1):12-9. 72. Watts J. Problems with the ICD-11 classification of personality disorder. The Lancet Psychiatry. 2019;6(6):461-3.

73. Sweeney A, Clement S, Filson B, Kennedy A. Trauma-informed mental healthcare in the UK: 89492. 
medRxiv preprint doi: https://doi.org/10.1101/2020.12.15.20248267; this version posted December 16, 2020. The copyright holder for this preprint (which was not certified by peer review) is the author/funder, who has granted medRxiv a license to display the preprint in perpetuity.

It is made available under a CC-BY-ND 4.0 International license .

895 74. Lloyd-Evans B, Bond GR, Ruud T, Ivanecka A, Gray R, Osborn D, et al. Development of a 896 measure of model fidelity for mental health Crisis Resolution Teams. BMC Psychiatry.

$897 \quad 2016 ; 16(1): 427$.

898 75. Lloyd-Evans B, Osborn D, Marston L, Lamb D, Ambler G, Hunter R, et al. The CORE service 899 improvement programme for mental health crisis resolution teams: results from a cluster-

900 randomised trial. Br J Psychiatry. 2020;216(6):314-22.

901 76. Dudas RB, Lovejoy C, Cassidy S, Allison C, Smith P, Baron-Cohen S. The overlap between 902 autistic spectrum conditions and borderline personality disorder. PLOS ONE [Internet]. 2017;

903 12(9):e0184447. DOI: 10.1371/journal.pone.0184447

90477 . Jennings $P$, Matheson-Monnet CB. Multi-agency mentoring pilot intervention for high

905 intensity service users of emergency public services: the Isle of Wight Integrated Recovery

906 Programme. Journal of Criminological Research, Policy and Practice. 2017;3(2):105-18. 
medRxiv preprint doi: https://doi.org/10.1101/2020.12.15.20248267; this version posted December 16, 2020. The copyright holder for this preprint (which was not certified by peer review) is the author/funder, who has granted medRxiv a license to display the preprint in perpetuity.

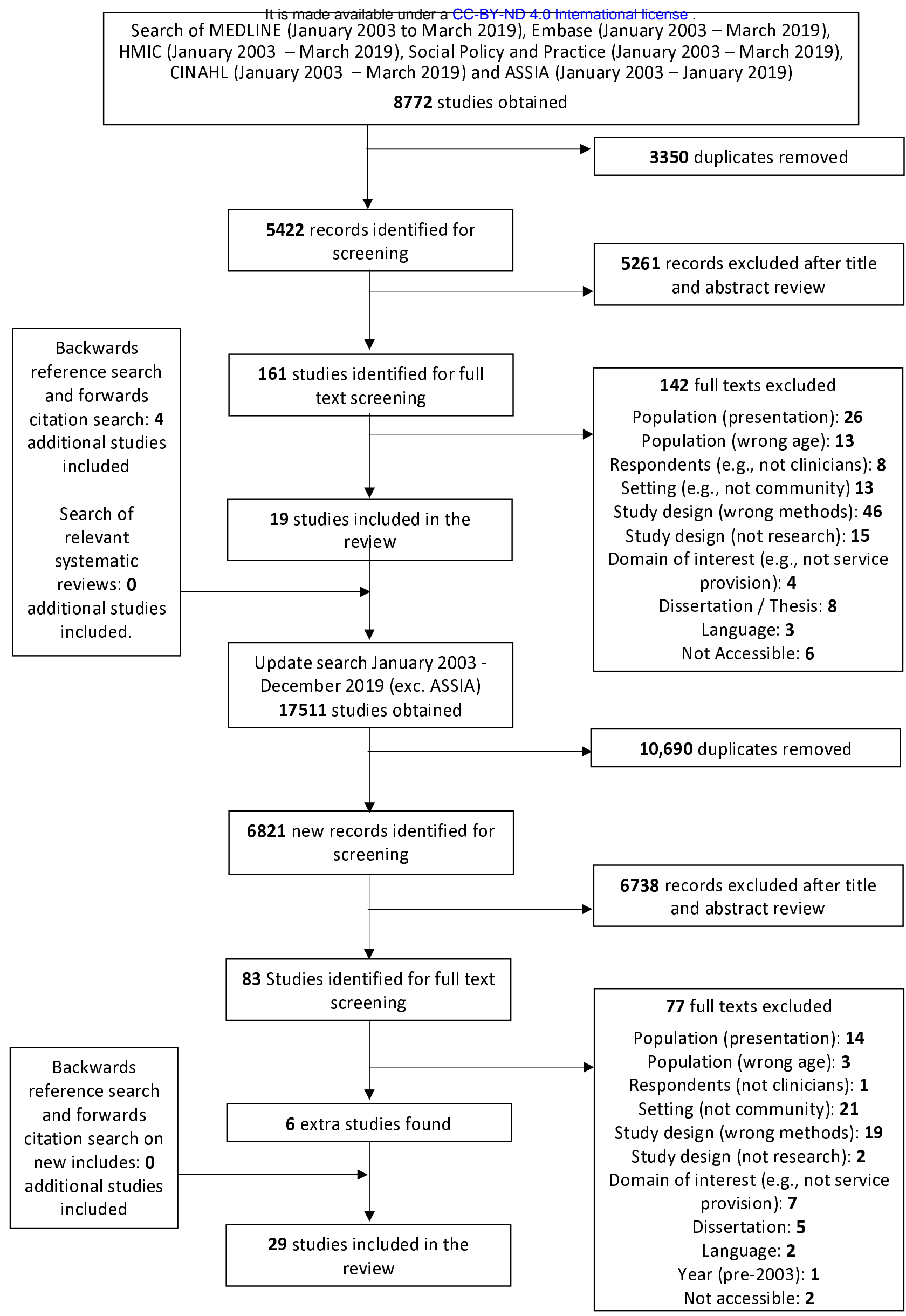

